\title{
The link between climate warming and break-up of ice shelves in the Antarctic Peninsula
}

\author{
Ted A. Scambos, ${ }^{1}$ Christina Hulbe, ${ }^{2}$ Mark Fahnestock, ${ }^{3}$ Jennifer Bohlander $^{1}$ \\ ${ }^{1}$ National Snow and Ice Data Center, University of Colorado, Boulder, Colorado 80309-0449, U.S.A. \\ ${ }^{2}$ Laboratory for Hydrospheric Processes, Goddard Space Flight Center, Greenbelt, Maryland 20771, U.S.A. \\ ${ }^{3}$ Earth System Science Interdisciplinary Center, University of Maryland, College Park, Maryland 20742, U.S.A.
}

\begin{abstract}
A review of in situ and remote-sensing data covering the ice shelves of the Antarctic Peninsula provides a series of characteristics closely associated with rapid shelf retreat: deeply embayed ice fronts; calving of myriad small elongate bergs in punctuated events; increasing flow speed; and the presence of melt ponds on the ice-shelf surface in the vicinity of the break-ups. As climate has warmed in the Antarctic Peninsula region, melt-season duration and the extent of ponding have increased. Most break-up events have occurred during longer melt seasons, suggesting that meltwater itself, not just warming, is responsible. Regions that show melting without pond formation are relatively unchanged. Melt ponds thus appear to be a robust harbinger of ice-shelf retreat. We use these observations to guide a model of ice-shelf flow and the effects of meltwater. Crevasses present in a region of surface ponding will likely fill to the brim with water. We hypothesize (building on Weertman (1973), Hughes (1983) and Van der Veen (1998)) that crevasse propagation by meltwater is the main mechanism by which ice shelves weaken and retreat. A thermodynamic finite-element model is used to evaluate ice flow and the strain field, and simple extensions of this model are used to investigate crack propagation by meltwater. The model results support the hypothesis.
\end{abstract}

\section{INTRODUGTION}

Peripheral ice shelves, unlike ice sheets, respond rapidly to climate condition; in fact, they apparently can respond faster than simple models of their behavior would predict. Over the last few decades, and particularly within the last 10 years, several ice shelves in the northern Antarctic Peninsula have rapidly retreated, essentially disappearing (see Fig. 1; Vaughan and Doake, 1996). As discussed below, morphological evidence, coupled with ice-flow speeds of the shelves, indicates that they have existed for centuries prior to this period. The only plausible cause for this sudden turn of events is the strong regional climate warming observed in the area over the same period (e.g. Doake and Vaughan, 1991; King, 1994; Vaughan and Doake, 1996; Comiso, 2000). Weather-station records from several stations in the Antarctic Peninsula indicate a $2.5^{\circ} \mathrm{C}$ warming trend in mean annual air temperature over the last 50 years. Coincident with this is a $20 \%$ reduction in sea-ice extent since 1978 in the Bellingshausen and Amundsen Seas, as determined by satellite passive-microwave records (Jacobs and Comiso, 1997). King (1994) showed that the ice extent and station temperatures are correlated in the Antarctic Peninsula.

The thermal response of ice shelves to surface warming is slow, because heat diffuses slowly through ice. However, warming that leads to melting and the accumulation of meltwater on the upper surface of an ice shelf may have other, more immediate, effects. We propose that surface melting which is extensive enough to form ponds of liquid water on the ice-shelf surface is an important contributor to the breakup of ice shelves. Occasional melting occurs over a wide area in Antarctica, but the formation of melt ponds implies that melting has proceeded to the point where the firn is saturated. Any surface crevasse in such an area will fill with water. Because water is denser than ice, the walls and tip of a waterfilled crevasse have an outward and downward pressure acting on them that may surpass the ice overburden pressure acting to close the fracture. Where crevasses are $\sim 90 \%$ filled, it is very likely that the water pressure will force crevasses to propagate through the full ice thickness.

By enabling a fracture to penetrate through the entire ice thickness, extensive surface melting compromises the mechanical integrity of any ice shelf with large areas of extensional or shearing stress. Thus, by acting on a relatively tiny fraction of the ice shelf, i.e. at the tips and walls of crevasses, the effect of a small thermal change at the surface is magnified, disrupting the stability of a huge mass of ice. The system is an example of how small changes in climate may have large, difficult-to-predict effects on earth systems.

This link between melt-ponding and ice-shelf break-up, developed below, is completely consistent with an earlier link noted by Mercer (1978): that Antarctic ice shelves do not exist northward of the line where mean annual temperatures average $>-5^{\circ} \mathrm{C}$. What was not appreciated at that time, and what motivates the hypothesis proposed here, is the rapidity of response to changes in the $-5^{\circ} \mathrm{C}$ line.

\section{OBSERVATIONS}

In this paper, we use the informal nomenclature of Vaughan and Doake (1996): the northernmost section of the Larsen Ice Shelf, between Robertson Island and the Sobral Peninsula, is 


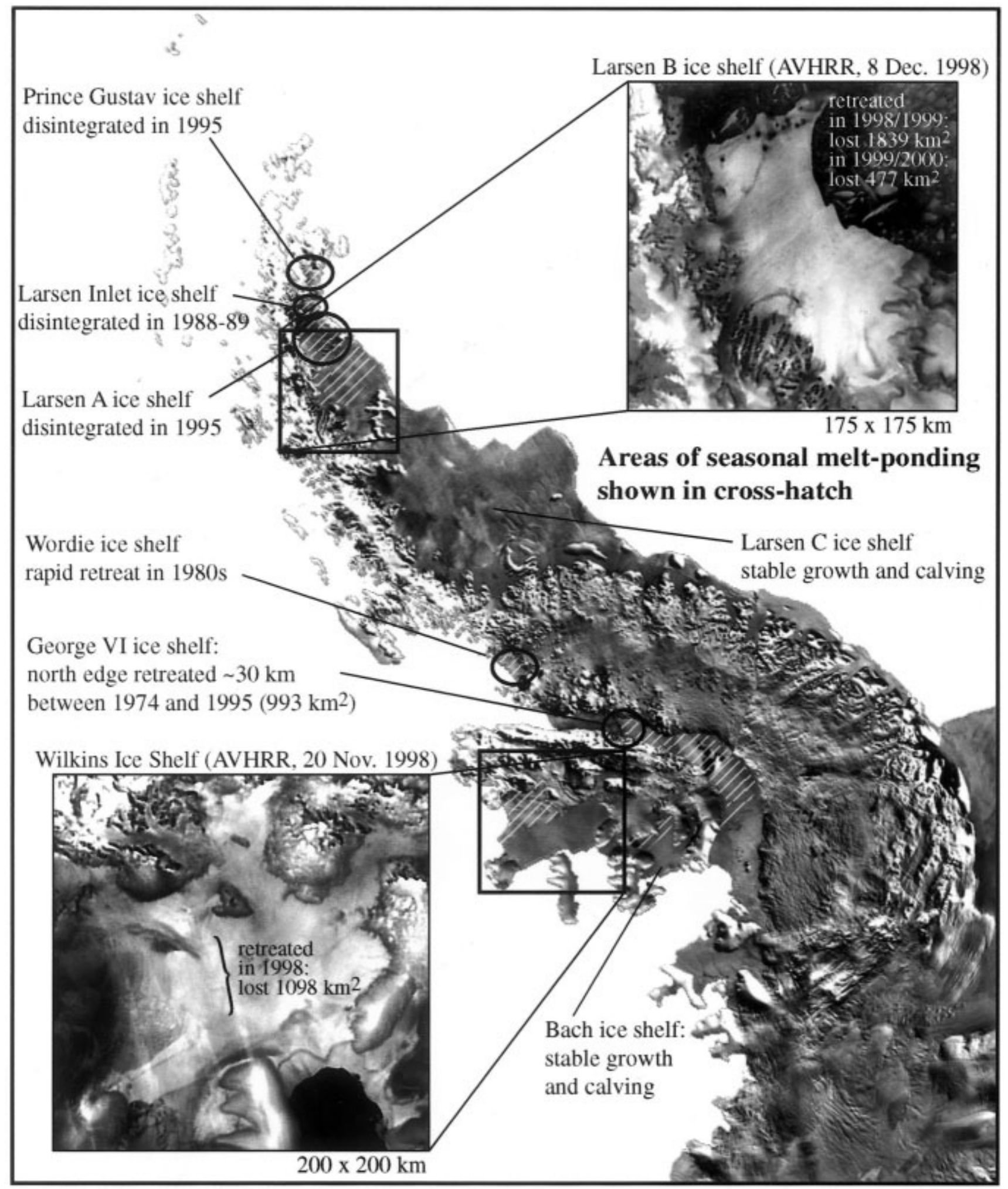

Fig. 1. Overview of the Antarctic Peninsula summarizing recent ice-shelf activity and its correlation with areas of melt-ponding. The base image of the peninsula is an AVHRR mosaic compiled from scenes acquired between 1980 and 1994 (from Ferrigno and others, 1996).

termed the Larsen "A"; the section between Robertson Island and the Jason Peninsula is the Larsen "B". The southern parts of the Larsen ("C", from Jason Peninsula to Gipps Ice Rise; and "D", from Gipps Ice Rise to Kemp Peninsula) are not discussed in detail here.

The ice shelves have existed for centuries prior to the last two decades

In enhanced Advanced Very High Resolution Radiometer (AVHRR) and synthetic-aperture radar (SAR) imagery, the surfaces of ice shelves show long linear streaks, generally oriented parallel to flow, termed "flowstripes". Although details of their formation are unclear, they are formed while the constituent ice is grounded. These features persist for many centuries and can serve as indicators of flow change (see, e.g., Fahnestock and others, in press). A 1992 SAR image of the Larsen A and B shows these flowstripe features clearly, in some cases extending over $80 \mathrm{~km}$ from the grounding line (Fig. 2). Other SAR images of the Larsen B show flowstripes extending further, to the former shelf front along most of its length (Rott and others, 1998). Their presence is an 


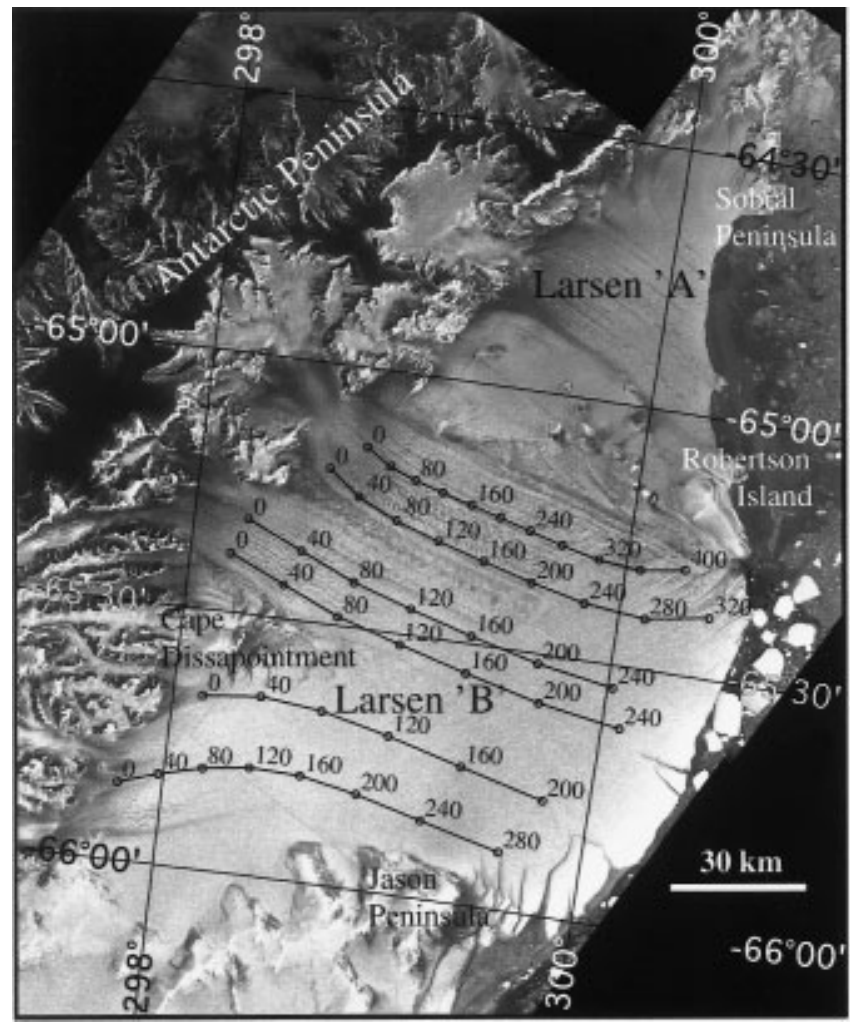

Fig. 2. Processed SAR mosaic (from the European Remotesensing Satellite ERS-1) of the late 1992 configuration of the northern Larsen ice shelves. Flowlines derived from the ice-shelf flow model are shown annotated with time-since-grounded ticks.

indicator that the shelf has existed, at a minimum, long enough for the ice to traverse the distance from the grounding line to the limit of their visibility. Combining the SAR image with velocity data derived from a model of ice-shelf flow (developed below) yields an estimate of a minimum age for the shelves. For the Larsen B, this is about 300 years.

The Wilkins Ice Shelf does not have extensive flowstripes. The constituent ice for the Wilkins is believed to form primarily from in situ accumulation (e.g. Vaughan and others, 1993). Therefore, thickness of the shelf divided by the accumulation rate provides one estimate of the minimum age (we assume there is no basal freezing for this relatively warm ice shelf). Surface elevation data from radar altimetry indicate a shelf thickness of 200-250 m for most of the shelf. With accumulation rates of $0.6-0.8 \mathrm{ma}^{-1}$ (Turner and others, 1998), 300-400 years is required to accumulate the shelf.

In one area in the southern part of the Wilkins Ice Shelf some flowstripes are observed, along with a slight thickening. This area is adjacent to the Lewis Ice Field, and Vaughan and others (1993) interpret it to be derived from ice flow originating there. The thickened area is approximately $80 \mathrm{~km}$ long in the flow direction. Flow speeds on the shelf are about $50 \mathrm{ma}^{-1}$. This implies that the southern area may have existed for roughly 1500 years.

The break-up events of the 1990s indicate that for the first time in the last few centuries the northern Antarctic Peninsula climate is incompatible with the presence of ice shelves. The shelf break-up events are therefore appropriately part of the debate concerning recent global warming.

The shelves underwent a distinct change in calving style, and began retreating, in the last 20 years

We use a combination of historical maps, aerial photos and satellite images to track the evolution of several Peninsular shelf regions over the last 100 years, relying in part on earlier work by Doake (1982), Skvarca (1993, 1994), Vaughan and others (1993), Rott and others (1996), Cooper (1997) and Lucchitta and Rosanova (1998). Although in recent years SAR satellites (e.g. RADARSAT) have provided good temporal and spatial coverage, previous coverage was more infrequent. An improvement in coverage, with some sacrifice in spatial detail, is available by using the AVHRR sensor on the U.S. National Oceanic and Atmospheric Administration's polar-orbiting weather satellites. The National Snow and Ice Data Center (NSIDC) at the University of Colorado maintains an archive of AVHRR-derived scenes of the Peninsula and northern West Antarctic ice shelves extending back to the late 1980s. The sensor flies over the Antarctic Peninsula several times per day, although cloud-free conditions occur over the areas of interest only about twice per month. AVHRR scenes document the evolution of the ice shelves in good temporal detail over the last decade. The images are available on the Internet at http://www-nsidc. colorado.edu/NSIDC/ICESHELVES. NSIDC has also acquired a set of declassified Defense Intelligence Satellite Program (DISP) images of the same shelves from the early 1960s, which provide an unambiguous mapping of the shelf extent at the very beginning of the satellite era. DISP images are available from the Earth Remote Observation System (EROS) Data Center at http://edcwww.cr.usgs. gov/dsprod/prod.html.

\section{Prince Gustav Ice Shelf, Larsen Inlet and Larsen Ice Shelf}

Figure 3 summarizes the record of shelf extent for the northern Larsen region available from maps and the NSIDC AVHRR archive. This and additional image and map information from Skvarca (1993, 1994), Rott and others (1996, 1998), Cooper (1997) and Skvarca and others (1999) are the basis for the following discussion.

There is some debate regarding the pre-1960 extent of the Larsen and Prince Gustav Ice Shelves north of Robertson Island. Nordenskjöld (1905) reported that in 1902 the Larsen shelf edge was even with Lindenberg Island, trending northsouth (see first tile in Fig. 3), and he had sledged on sea ice between Cape Foster and Robertson Island. This indicates a slightly embayed front and relative separation of the Larsen A, Larsen Inlet and Prince Gustav shelves; the front he reported near Lindenberg Island is similar to that observed in a 1963 satellite image (fourth tile of Fig. 3). However, British sledging expedition reports in the late 1940s suggest the Prince Gustav, Larsen Inlet and Larsen A ice-shelf fronts had merged, extending from Cape Foster to Robertson Island (Koerner, 1961; Doake, 1982; Cooper, 1997). Other compilations from aerial overflights and field expeditions suggest that, while the shelf front had grown since 1902 and bulged eastward, the shelf ice-front line still extended from Robertson Island to Cape Longing, and not across Prince Gustav Channel to Cape Foster. For a summary, see Bertrand (1971) and the American Geographical Society (AGS) map of Antarctica dated 1962 (AGS, 1962). An excerpt from this 1962 map is shown in the second tile of Figure 3. The map fails to indicate the Prince Gustav Ice Shelf, but nevertheless summarizes overflight and pilot report data for the northern Larsen up to 1947. A revised AGS map compiled in 1971 (AGS, 1971) showed an embayed front in 1961, a shape largely verified by the first satellite images from 1963 (see third and fourth tiles of Fig. 3).

The series of early observations are reconcilable by a 
$1902-1935$

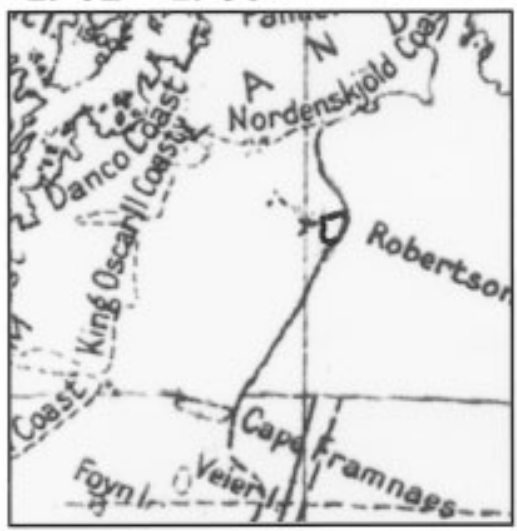

Nordenskjöld's log, overflights

29 Aug. 1963

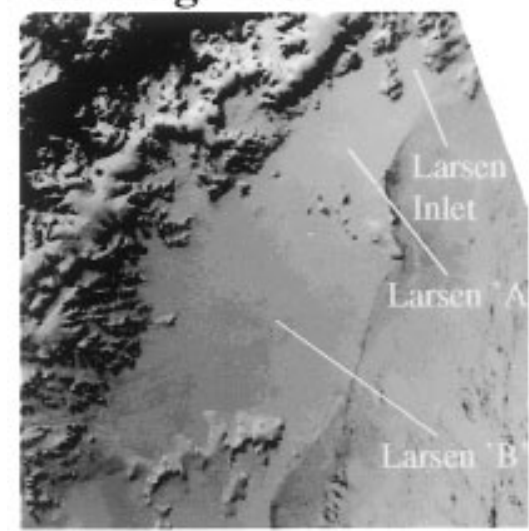

DISP program, visible/near-IR

22 March1998

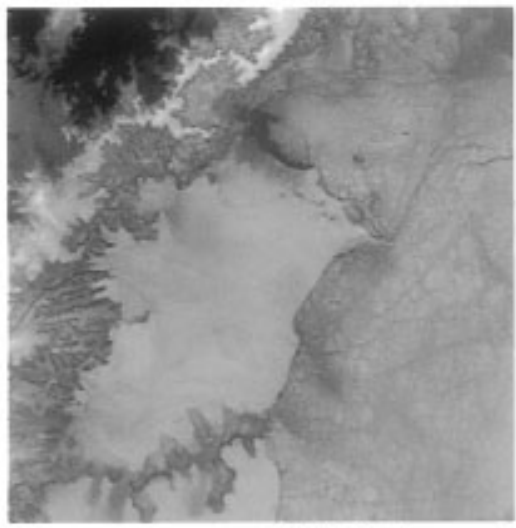

AVHRR, thermal
1947

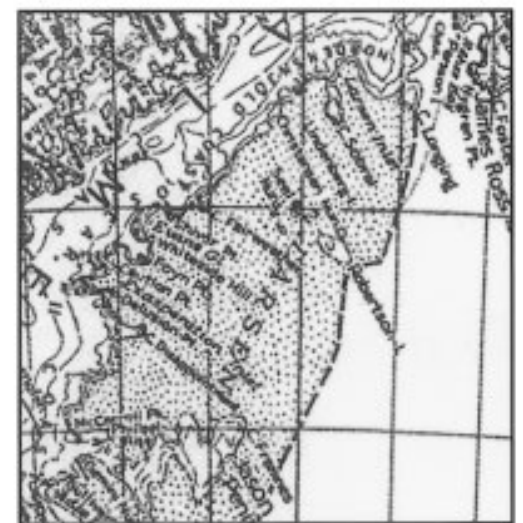

AGS 1962 map (aerial photos)

\section{Dec. 1993}

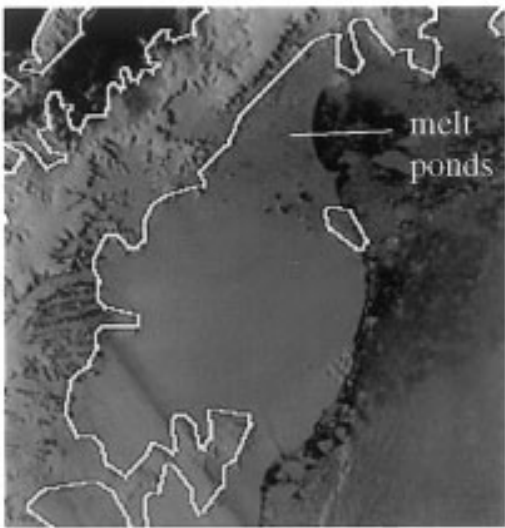

AVHRR, visible/near-IR

20 Nov. 1998

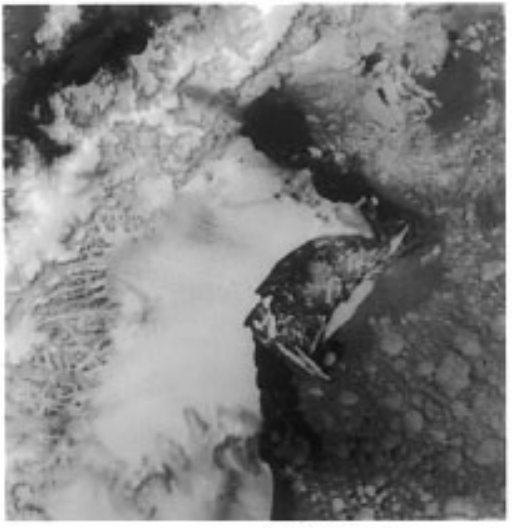

AVHRR, thermal
1961

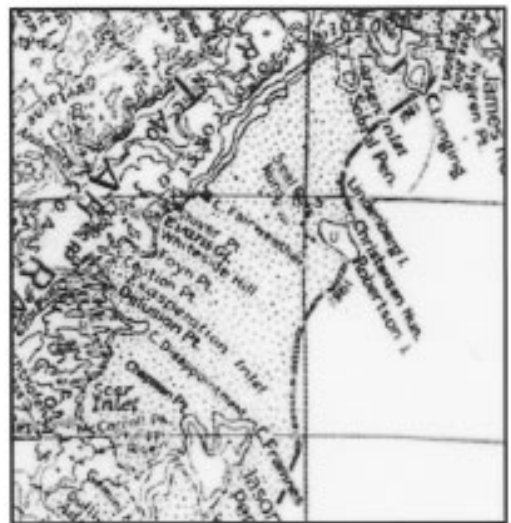

AGS 1971 map (aerial photos)

\section{Feb. 1995}

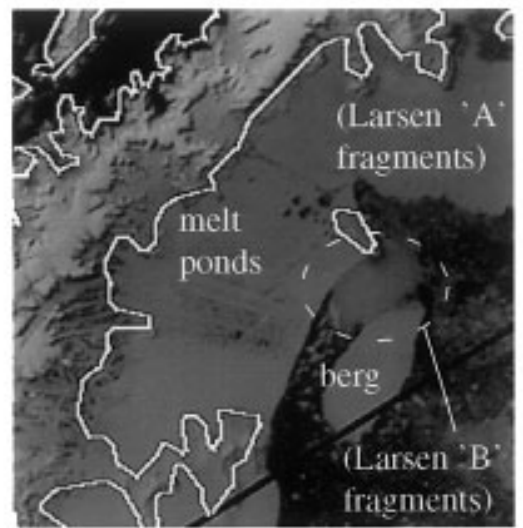

AVHRR, visible/near-IR

\section{March 2000}

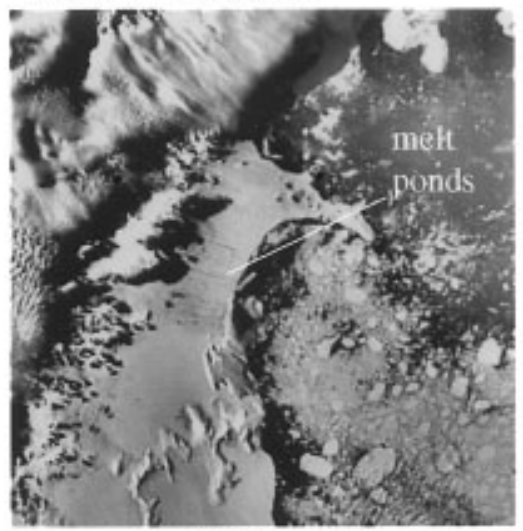

AVHRR, visible/near-IR

Fig. 3. Map and satellite-image summary of the recent history of the northern Larsen Ice Shelf.

pattern of ice-shelf growth and retreat by large-berg calving in the Larsen A area between 1902 and 1963, coupled with an extensive "shelf" of multi-year fast ice between Robertson Island and Cape Foster in the 1940s. Satellite images from the 1970s frequently show a large fast-ice area in front of the northern Larsen (see Skvarca, 1993, 1994). Nordenskjöld's (1905) observations (sea ice between Robertson and Cape Forster) in 1092 are unambiguous, but in general there seems to have been a problem distinguishing between fast ice and shelf ice further to the north in later decades. Indirect support for the fast-ice-shelf suggestion comes from a consideration of ice-flow speeds. Bindschadler and others (1994) used satellite image pairs to measure an ice-flow speed of $309 \pm 6 \mathrm{~m} \mathrm{a}^{-1}$ for the Larsen Inlet. Given the Nordenskjöld ice front in 1902 (assuming it is similar to the 1963 front), an advance of somewhat less than $15 \mathrm{~km}$ would be expected by the late $1940 \mathrm{~s}$. The ice-front reports summarized by Doake (1982) and Cooper (1997) for this time would imply a $40 \mathrm{~km}$ advance.

The Larsen A and Larsen Inlet ice fronts advanced from 1963 until approximately 1975. At that time, the cycle of advance and large-berg calving on a quasi-regular period was replaced by punctuated retreats through mass calving of small elongate bergs. The Larsen Inlet suffered a major retreat in early 1987, and again in early 1989 (see Skvarca, 1993, 1994). The Larsen A retreated in steps, culminating in a spectacular disintegration in late January 1995 (Skvarca 1993, 1994; Rott and others, 1996).

The history of the Larsen B ice front is relatively well documented. The ice front south of Robertson Island in the direction of Jason Peninsula is reported as relatively straight according to Nordenskjöld in 1902, bowed seaward in 1947 (AGS, 1962) and significantly embayed in 1961 (AGS, 1971 
and DISP satellite imagery from 1963). The pattern is consistent with a growth and large-berg calving pattern with a $\sim 50$ year cycle, similar to the Larsen A. The later tiles in Figure 3, and Soyuzkarta and Landsat images published by Skvarca (1993, 1994), document continued growth. Unlike the Larsen A and Larsen Inlet, growth on the Larsen B continued until early 1995. In late January 1995, the same storm that initiated the final disintegration of the Larsen A caused the calving of a large tabular berg $\left(\sim 1700 \mathrm{~km}^{2}\right)$ and $\sim 550 \mathrm{~km}^{2}$ of small tabular bergs from the front of the Larsen B. After this event, the Larsen B has followed the shelfretreat pattern begun earlier by the Larsen A: punctuated retreats of smaller elongate bergs and a rapid, deep embayment of the ice front well beyond its historical minimum extent. The events comprising this retreat occur over a period of a few days, often near the end of the melt season (e.g. February through early April). In late February 1998 a retreat event of $\sim 125 \mathrm{~km}^{2}$ occurred, marking the first embayment of the ice shelf inside the line between Robertson Island and the eastern Jason Peninsula. This line was identified as the location of a "compressive arch" in a shelf model run by Doake and others (1998). Disruption of the arch was expected to increase the rate of shelf retreat. Indeed, in early November of the same year a much larger retreat event $\left(\sim 1042 \mathrm{~km}^{2}\right)$ occurred. An additional $676 \mathrm{~km}^{2}$ retreat occurred in several events during January-March 1999, resulting in a total loss of $1839 \mathrm{~km}^{2}$ for the 1998-99 melt season. For the 1999-2000 melt season, an additional $477 \mathrm{~km}^{2}$ was lost. The area lost by the Larsen B has come largely from the northern two-thirds of the shelf.

\section{Wilkins and George VI Ice Shelves}

Figure 4 summarizes the image and map documentation of ice-shelf extent for the Wilkins. This study adds to the record discussed in Vaughan and others (1993) and Lucchitta and Rosanova (1998) by incorporating additional images from the AVHRR archive at NSIDC, allowing for better temporal resolution of some break-up events. The extent of the Wilkins Ice Shelf was first mapped by aerial photography in 1947. This extent is shown in the AGS map of 1962 (AGS, 1962; tile 1 of Fig. 4). A comparison with DISP image data from 1963 (tile 2 of Fig. 4) shows no unambiguous changes, given the geographical and geolocation errors of the earlier map (note, e.g., Latady and Dorsey Islands). Comparison between the 1963 image and an early Landsat image from 1974 (in Lucchitta and Rosanova, 1998) indicates no major difference in shelf extent from the 1963 scene, although the 1974 image shows melt ponds in the northeastern corner of the shelf.

Vaughan and others (1993) discuss the extent of the shelf and its surface features, based on Landsat images from 1986 and 1990. Comparison of the 1974 and 1986 images shows a minor retreat in the northeastern corner of the shelf of about $8 \mathrm{~km}$, representing a shelf area of approximately $350 \mathrm{~km}^{2}$, and a minor retreat on the front between Latady Island and Mendelssohn Inlet. The 1986 Landsat image records the northern retreat in progress, with elongate bergs recently calved from the northeastern front, and abundant melt-ponding. Lucchitta and Rosanova (1998) compare the 1974 image with a 1992 SAR image and find a retreat of nearly $800 \mathrm{~km}^{2}$ between the two, indicative of an additional $550 \mathrm{~km}^{2}$ retreat between 1986 and 1992. Inspection of AVHRR image data from that period suggests that part of the additional retreat occurred in 1989, when a northward-projecting feature of the northern front disappeared. However, part of the meas- ured retreat is occurring as the 1992 image is acquired; the SAR data show recently calved elongate bergs and melt ponds in the northeast corner of the shelf.

AVHRR images shown here, and SAR data reported in Lucchitta and Rosanova (1998), indicate that the northeastern corner of the Wilkins Ice Shelf underwent an additional rapid break-up in late austral summer 1993. In the 13 January 1993 AVHRR image tile of Figure 4, extensive melt ponds are seen in the northeastern Wilkins Ice Shelf (and were observed over the entirety of the George VI Ice Shelf, and the northern portion of the Bach Ice Shelf, not shown in Figure 4). The image also refines the timing of the largest portion of a retreat event described in Lucchitta and Rosanova (1998). However, in their October 1995 image, the break-up appears to be continuing, and cracks are observed across the entire northern front of the shelf. AVHRR monitoring between 1995 and early 1998 shows no additional retreat, and in fact the elongate icebergs generated by the earlier break-up are incorporated into multi-year fast ice that remains intact through the warm season.

A very extensive retreat occurred in early 1998. AVHRR images from early March 1998 show a large calving bay, $40 \mathrm{~km}$ wide and reaching $50 \mathrm{~km}$ into the shelf on the northwestern side. The western portion of the fast ice and entrapped elongate bergs, as well as $1098 \mathrm{~km}^{2}$ of shelf ice, disintegrated in the retreat event. It is recorded vividly in the 16 August 1998 SAR image shown in Figure 4. At the time the image was acquired, winter-season fast ice had regrown and trapped the new icebergs. Bergs calved during the earlier events of 1993 and 1995 are still encased in multi-year fast ice on the eastern side of the image.

In summary, the Wilkins Ice Shelf was a stable and slowly evolving shelf between 1947 and the mid-1980s. Beginning in 1986, this pattern changed, and a series of retreats of the northern shelf edge occurred. As with the Larsen, the retreat events are characterized by episodic calving of many small elongate bergs.

For a discussion of the recent history of retreat of the George VI Ice Shelf, see Lucchitta and Rosanova (1998) and the references cited therein. The northern edge of this shelf has retreated relatively steadily since it was first observed in 1936, with small retreat events occurring in 1977, 1979, 1981 and sometime between 1992 and 1995. The ice shelf lost nearly $1000 \mathrm{~km}^{2}$ between 1974 and 1995. Since 1995 the front has been stable: AVHRR images from February 2000 indicate no detectable change in the front shape or position relative to the 1995 SAR data of Lucchitta and Rosanova (1998). Retreat along the northern edge is similar to the retreat pattern of the Wilkins Ice Shelf, in that a break-up event may release many small icebergs, generally elongate in shape, which are then often retained near the front in multiyear fast ice for several years.

\section{Melt-season duration and melt-ponding have increased during the last two decades}

Passive-microwave emission from a snow or ice surface undergoes a dramatic change when the surface is partly melted. Because of a reduction in surface emissivity, the brightness temperature of the emitted radiation in the microwave spectral range drops. This change has been used to track the duration of the melt season in Greenland (Abdalati and Steffen, 1997) and Antarctica (Zwally and Fiegles, 1994).

Applying a new algorithm designed to reduce problems 
1947

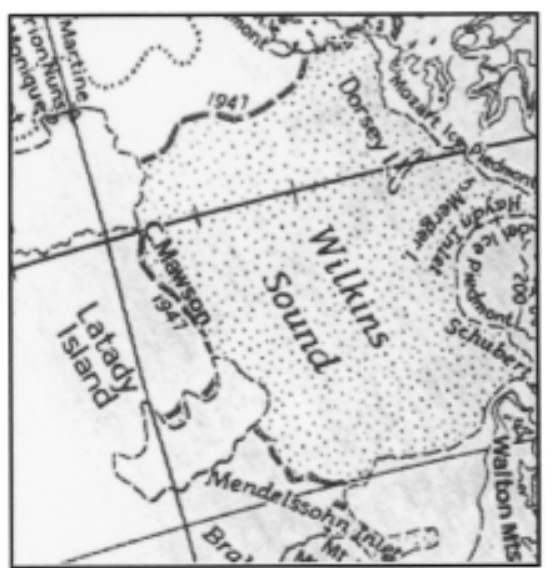

AGS 1971 map (aerial photos)

\section{Aug.1963}

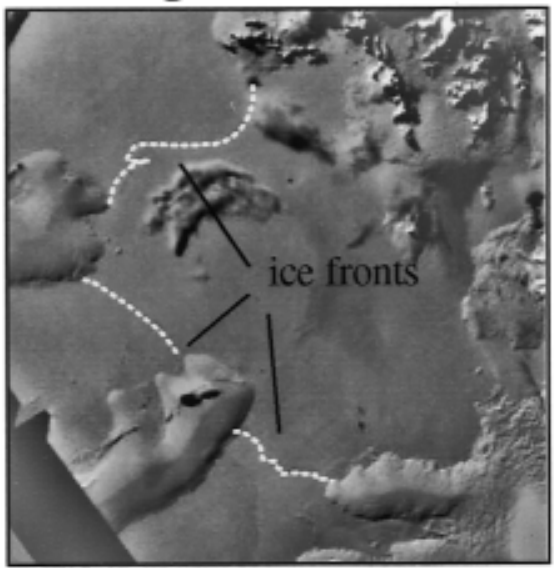

DISP program, visible/near-IR
11 April 1992

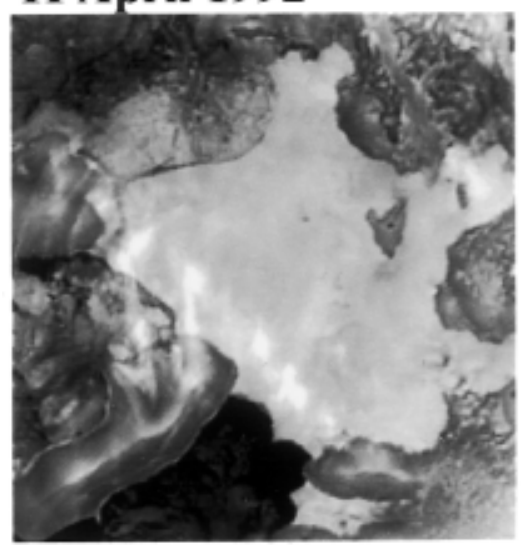

AVHRR, thermal
13 Jan. 1993

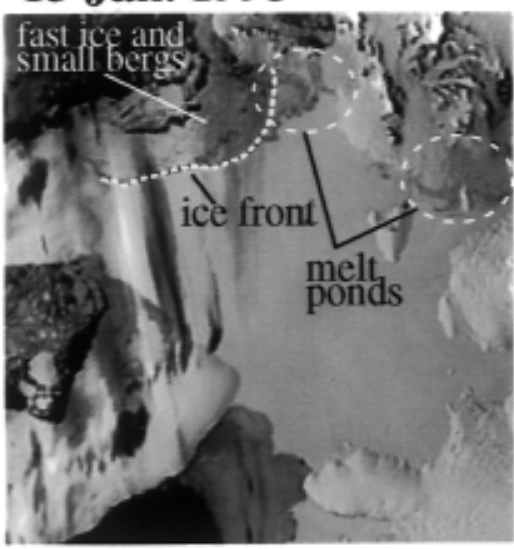

AVHRR, visible/near-IR

\section{March 1998}

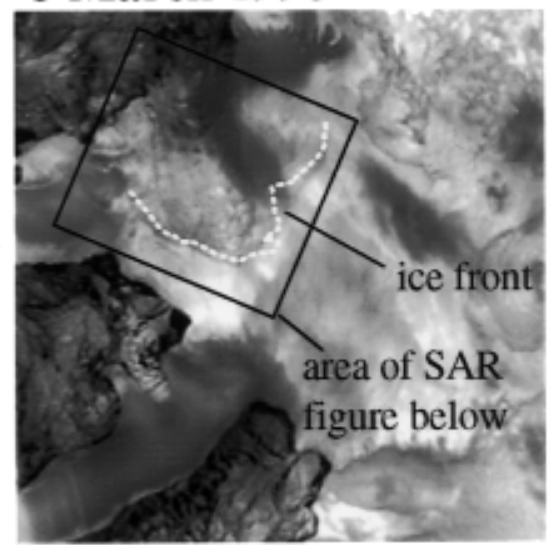

AVHRR, thermal

\section{Aug. 1998}

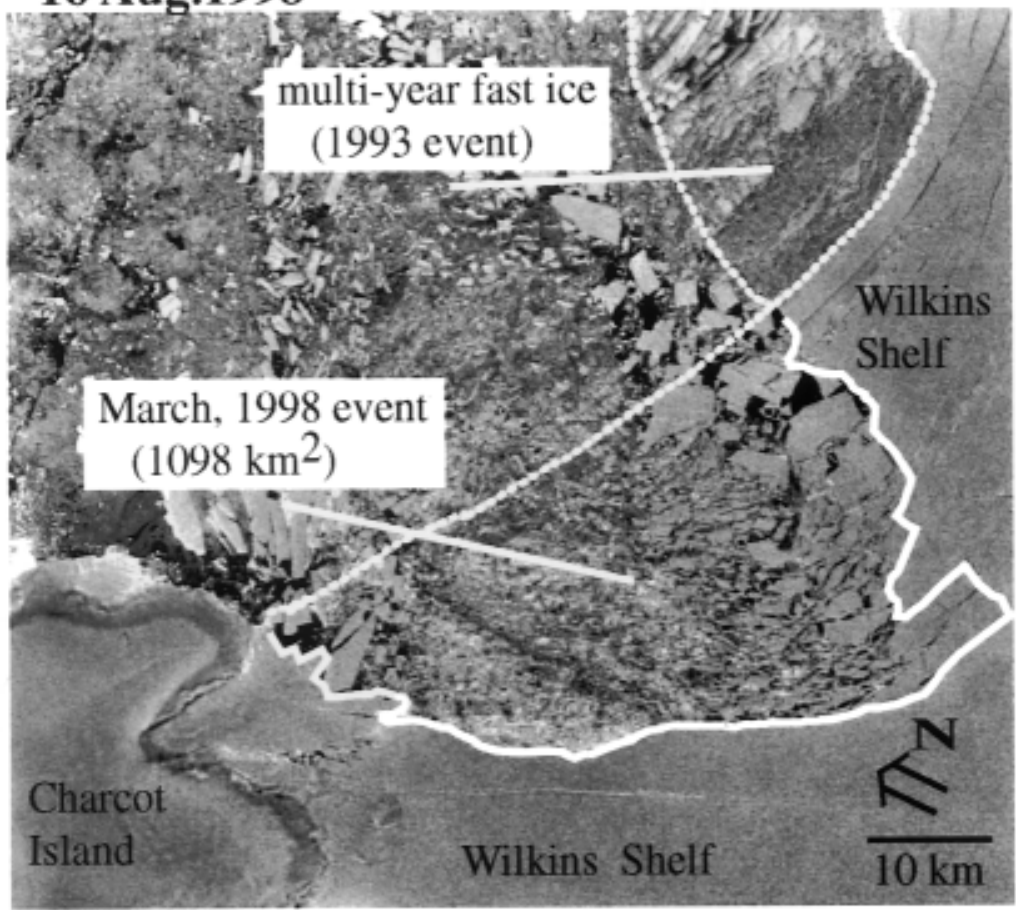

Radarsat, SAR

Fig. 4. Map and satellite-image summary of the recent history of the Wilkins Ice Shelf.

with extensive melting (a false melt-day signal can occur in other algorithms just after freeze-up of saturated firn), Fahnestock and others (1998) tracked the melt-season duration in the Antarctic Peninsula for the available record of satellite passive-microwave data (1978-96). The new algorithm uses a histogram of the passive-microwave characteristics of a single pixel over the course of a year, and identifies the break between frozen and melted surface as the break in the bimodal distribution of the histogram. In the areas studied, the break is very sharp. The estimated error in total melt days 
Larsen area annual total melt days and break-up events

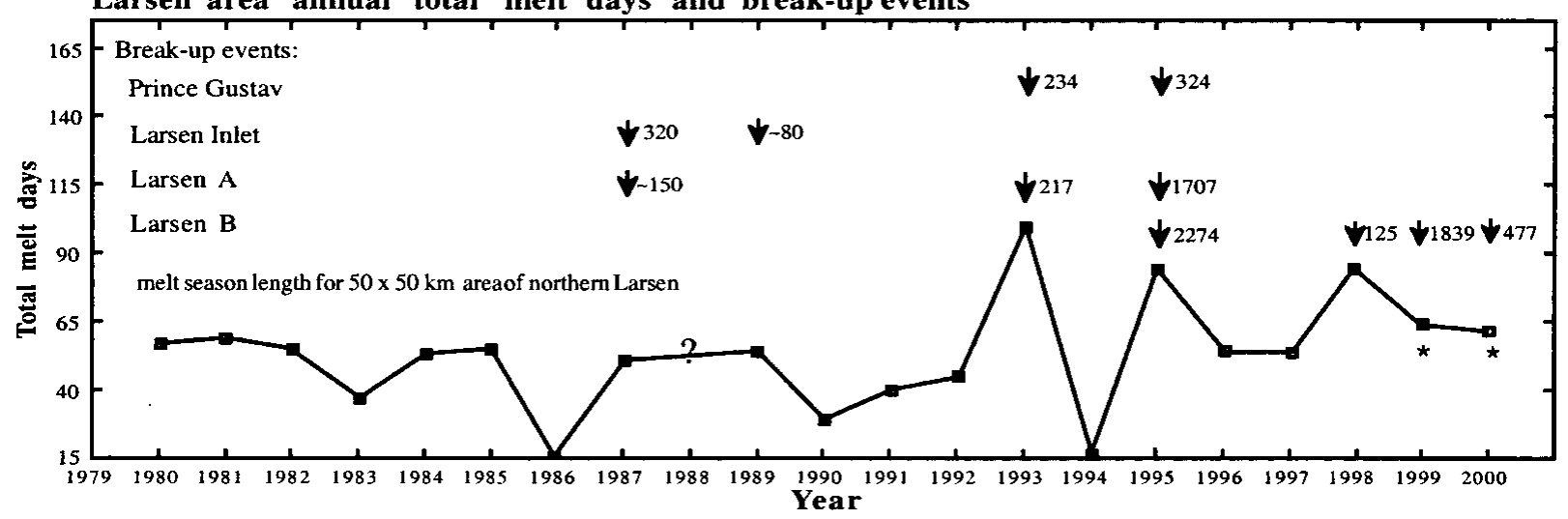

Wilkins area annual total melt days and break-up events

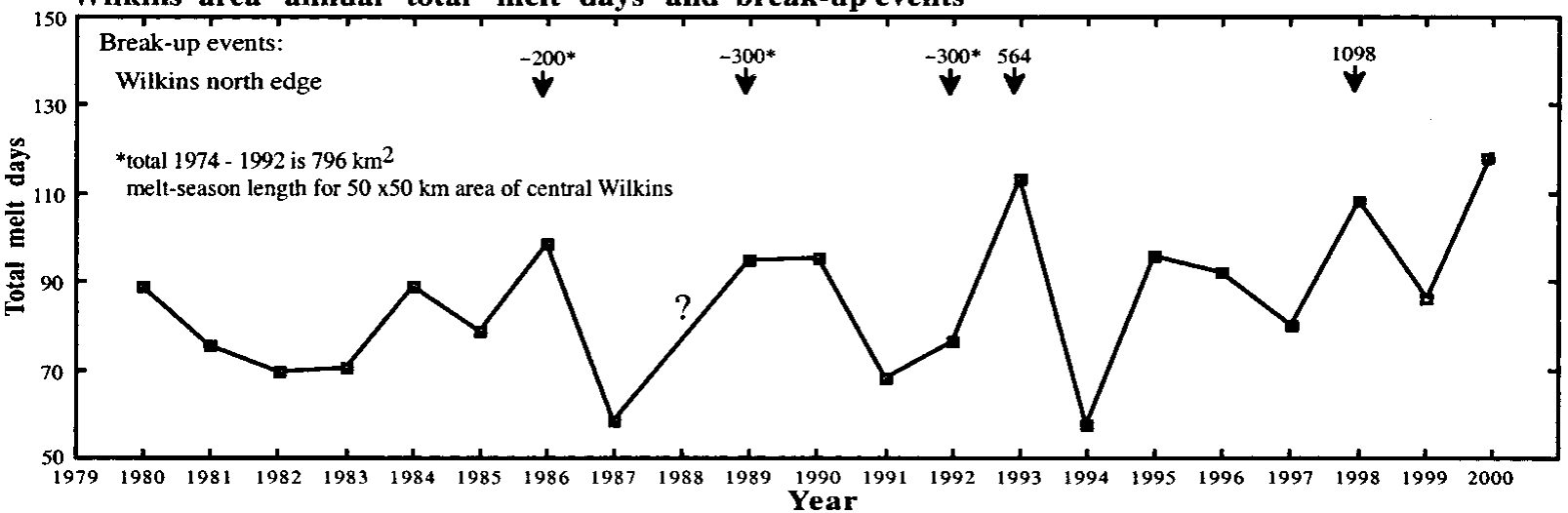

Fig. 5. Annual total melt days and recent break-up events in the Antarctic Peninsula. Melt-season duration was derived from passivemicrowave data using the Fahnestock and others (1998) algorithm. All major break-up events ( $\left.>100 \mathrm{~km}^{2}\right)$ that could be clearly attributed to a single year are shown. "Year" refers to the calendar year at the end of the melt season. Asterisk for 1999 and 2000 indicates melt days for region of northernmost Larsen C, since sample region of Larsen B for previous years had partially calved away.

for a season is roughly 2-4 days. Fahnestock and others (1998) observed a longer melt-season duration in the 1990s and suggested that these longer seasons are closely associated with break-up events in the Peninsular shelves; specifically that break-ups tend to occur during or towards the latter part of longer melt seasons.

The link between the length of the melt season and iceshelf retreat for the Larsen B and Wilkins ice shelves is examined in Figure 5. This plot shows the melt-season duration for two $50 \mathrm{~km}$ by $50 \mathrm{~km}$ areas (2-by-2 pixel blocks in the gridded microwave data) of the Larsen $\mathrm{B}$ and Wilkins ice shelves. The time period of the earlier study is extended to include the 1997-2000 data. The break-up data are derived by combining information from the AVHRR image record at NSIDC with SAR, Landsat and Soyuzkarta images from other published studies (Skvarca, 1993, 1994; Vaughan and others, 1993; Rott and others, 1996; Cooper, 1997; Lucchitta and Rosanova, 1998; Rott and others, 1998). Break-up events that can be assigned to a specific year are indicated above the melt-duration trend. The majority of the events are indeed associated with longer melt-season years, particularly 1986, 1993, 1995, 1998, 1999 and 2000, although some events occur in less extreme seasons. Note that for some shelves the ice had essentially disappeared by the latter part of the record and thus could not factor into the analysis.

The history of mean total melt days for the available passive-microwave record is summarized in Table 1. Melt seasons on both sides of the Antarctic Peninsula are longer by 11-14 days on average, and up to 22 days if 1994, an anomalously low year, is excluded. A broader study of melting on the Antarctic Peninsula ice shelves (Ridley, 1993) also concluded that the number of melt days had increased significantly in the period 1978-91. Ridley's study did not include the very high melt years of the mid- and late 1990s.

Greater melt duration is associated with increased ponding on the surface, but the relationship is not a simple one. In the northern Larsen, ponding occurs when the total melt days exceed about 50 in a given year. In the AVHRR record, melt-ponding is observed for the first time in 1993. Skvarca and others (1999) noted in their review of satellite images that late-summer Landsat data in the 1980s did not show melt features. During the extreme melt season of 1993, however, areas of the Larsen $\mathrm{C}$ far exceeded this value without showing ponding on the surface. The lack of surface ponds implies that firn pore space was not completely saturated, or that meltwater was able to flow off the shelf entirely. The Wilkins Ice Shelf also appears to tolerate a greater number of melt days without ponding, perhaps due to a higher accumulation rate, and thus more pore space to absorb meltwater (a

Table 1. Annual total melt days for Wilkins and Larsen B Ice Shelves, 1980-98
$1980-85$
$1980-98$
1993-98
1993-98 excl. 1994

$\begin{array}{lllll}\text { Larsen B } & 56(8) & 54(20) & 67(25) & 77(15) \\ \text { Wilkins } & 77(8) & 84(16) & 91(19) & 98(12)\end{array}$

Notes: Numbers in parentheses are standard deviations. Annual melt-day total derived from passive-microwave data (Fahnestock and others, 1998). Meltday totals determined for $50 \mathrm{~km}$ by $50 \mathrm{~km}$ areas in the northern Larsen B and central Wilkins Ice Shelves. Year refers to calendar year at the end of the melt season. Because of missing data, 1988 could not be included. 
similar relationship is noted for the George VI Ice Shelf; see Reynolds, 1981). Ponding is observed on the Wilkins Ice Shelf when the number of melt days exceeds about 70 .

Melt ponds are distributed differently on the Wilkins and Larsen Ice Shelves. In the area of the Larsen A and B, melt ponds are found along the flowstripe troughs and are thus oriented parallel to these features. In the available record of AVHRR scenes, melt-ponding is observed to begin on the Larsen A and in the region of the Larsen B just in front of Evans Glacier. As the melt season progresses, the region of ponding moves southward and eastward. The limit of melt-pond extent for the 1990s seasons is the line from Cape Disappointment to the front. In 2000, however, some melt ponds were observed a few kilometers south of this line for the first time (in AVHRR images). The Wilkins Ice Shelf shows frequent melt-ponding in its northeastern corner and at the base of the flanking mountains along its eastern grounding line, particularly near the Haydn Inlet. Melt ponds are more randomly oriented on the Wilkins Ice Shelf, which in general lacks flow features.

The relationship between ponding and break-up events is particularly apparent for the Larsen B; the northern twothirds of the shelf, the region of frequent ponding, has seen the greatest retreat. For the 1995 calving event, much of the northern shelf-front retreat was comprised of smaller bergs; the large berg was derived mainly from the southern part of the shelf (Figs 2 and 3; see also Rott and others, 1996). In the calving events of 1998, 1999 and 2000, the northern section has retreated significantly more than the southern section of the shelf.

The ice shelf in the Antarctic Peninsula with the most extensive melt-ponding, and the longest history of ponding, is the George VI Ice Shelf, which appears to be retreating only slowly (Wager, 1972; Reynolds, 1981; Lucchitta and Rosanova, 1998). Thus an additional factor (at least) must be required for rapid break-up in concert with melt-ponding. Ponding has been observed on the George VI Ice Shelf since the early 1940s, and begins to appear in December after approximately 40 days of melting. In the AVHRR record spanning the period 1989-2000, ponding is observed every year except 1994, most frequently and earliest in the region between Fossil Bluff and Ablation Point. This early onset and extensive development of melt-ponding may be due in part to the relatively low accumulation on the shelf $\left(<0.2 \mathrm{~m} \mathrm{a}^{-1}\right.$ according to Reynolds, 1981) and to warm downslope winds from the mountains flanking the shelf.

A careful survey of the southern Larsen, Venable, Abbot and Getz Ice Shelves using AVHRR images spanning the period 1989-2000 shows no melt-ponding and no evidence of significant retreat. The Bach Ice Shelf was observed to have melt ponds during the record melt season of 1993, but its extent has changed little over the available period of record (1963-2000).

\section{The Larsen B flow speed increased prior to break-up}

Stake measurements and image-mapping techniques indicate that the Larsen B significantly increased in flow speed in the decade prior to the break-up events, and particularly in the years just prior to disintegration (Rott and others, 1998; Rack and others, 1999). The Larsen B flow speed was determined by repeat measurement of stake positions (Rott and others, 1998). Sixteen stakes in a line between Seal Nunataks and the Jason Peninsula, roughly parallel to the
1995-98 ice front, were tracked between 1984 and 1996. In the period 1984-94, the mean displacement of the central stake was $383 \mathrm{~m} \mathrm{a}^{-1}$. Between 1994 and 1996, this increased to $442 \mathrm{~m} \mathrm{a}^{-1}$. Similar speed increases of $10-20 \%$ occurred at the adjacent stakes. For the Larsen A, the situation is less clear. The Larsen A flow speeds were determined by tracking displacements of specific features in several satellite images spanning the period 1975-95, supplemented by field measurements. For the Larsen A, a determination of ice speed over the period 1975-86 (Bindschadler and others, 1994) indicates speeds 5-35\% slower than measurements made in the interval 1984-94 (Bindschadler and others, 1994). However, the early imagery used in this comparison is relatively low-resolution and low-contrast, and provided relatively few velocity vectors. Speeds determined by both field measurement and image analysis during the 10 year period 1984-94 remained almost constant, but a slight increase was observed in the period just before break-up of the Larsen A in 1995 (Rack and others, 1999).

\section{Summary of observations}

Several characteristics stand out in the above observations and the cited literature concerning climate warming and Peninsula ice-shelf retreat. Rapid retreat of the shelves began in the 1970s-1980s; a review of the historical record indicates distinct changes in the pattern of front growth and retreat for several shelves at that time. During this period, air temperatures increased, sea-ice extent declined and the total number of melt days increased. Ponded melt began to be observed on the surface. Rapid break-ups are characterized by calving of large numbers of smaller elongate icebergs in regions of meltponding, with long axes oriented parallel to the ice front, in contrast to the calving of large tabular icebergs that is typical of stable ice shelves. The ice-flow speed increases as calving fronts retreat. Of primary importance, apparently, is the correlation between visible melt ponds during mid- to late summer and rapid break-ups. Spatially, this link is very clear; temporally, there is a good, but more approximate, link between extensive melt seasons, ponding and break-up events. We use these observations as a basis for designing model experiments to investigate shelf-retreat mechanisms.

\section{NUMERICAL MODEL}

We investigate the role of surface meltwater in ice-shelf retreat using a dynamic/thermodynamic numerical model of the northern Larsen Ice Shelf and a simple model of water-enhanced fracture propagation in ice. The numerical model solves stress-balance and heat-balance equations, represented by piecewise linear functions in a finite-element mesh that embodies the ice shelf (Fig. 6). Ice temperature is computed at 21 vertical nodes, which descend beneath each horizontal mesh node, using a stretch-coordinate scheme. Several model domains, which represent different ice-shelf front locations, are employed. The grounding line is selected according to the map of Skvarca (1994).

Ice shelves flow by gravity-driven horizontal spreading. This is described in the model by a set of stress-balance equations, simplified by assuming that horizontal flow is depth-independent. The equations are derived in MacAyeal and Thomas (1982) and are similar to those of Rommelaere and Ritz (1996) and Morland's (1987) "reduced" model. The constitutive relation for ice is embodied by an effective vis- 


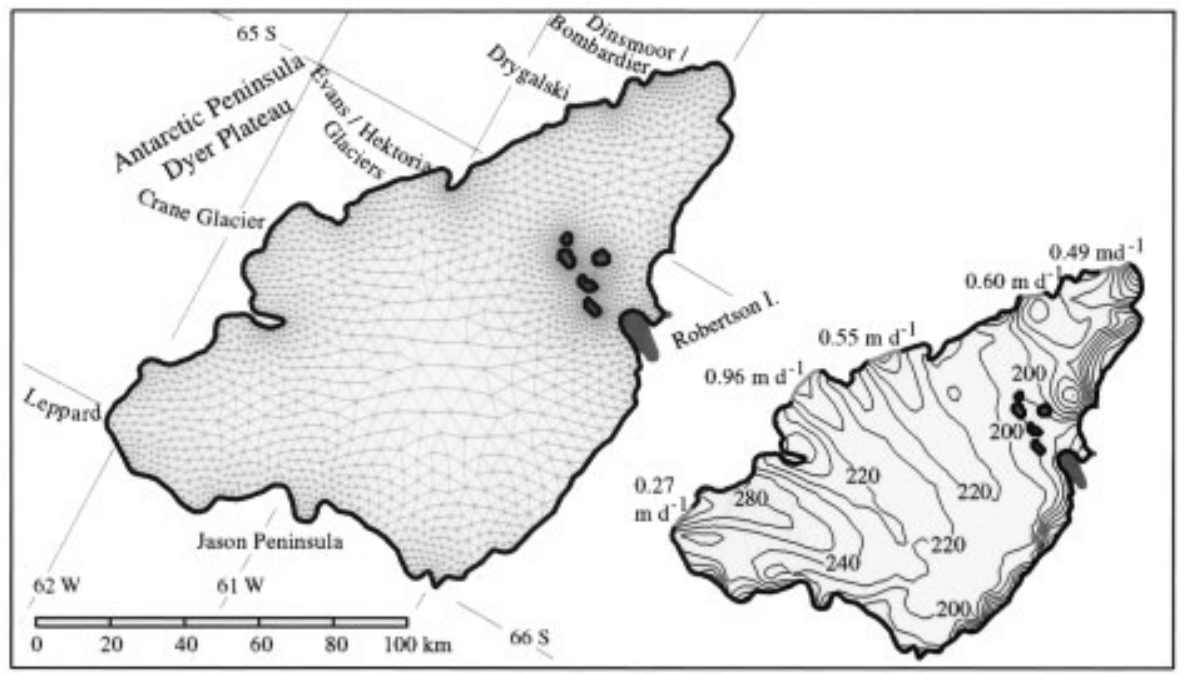

Fig. 6. Template used to create meshes for the numerical experiments. The finite-element mesh used in thermal experiments and to compute pre-1995 ice flow is inscribed within the Larsen A and B domain. Smaller, post-Fanuary 1995, domains are also used. Ice velocity and temperature conditions are specified for the Graham Land outlet glaciers noted in the figure. The inset showe the specified inflow speeds and ice thickness, with a contour interval of $20 \mathrm{~m}$. Inflow gates along the grounding line are highlighted in grey.

cosity, $v_{\mathrm{e}}$, using Glen's flow law for ice and the assumption of incompressibility. It is defined using a depth-averaged rate factor, $\bar{B}$, and flow-law exponent, $n$ :

$$
v_{\mathrm{e}}=\frac{\bar{B}}{2\left[\left(\frac{\partial u}{\partial x}\right)^{2}+\left(\frac{\partial v}{\partial y}\right)^{2}+\frac{1}{4}\left(\frac{\partial u}{\partial y}+\frac{\partial v}{\partial x}\right)^{2}+\frac{\partial u}{\partial x} \frac{\partial v}{\partial y}\right]^{\frac{n-1}{n}}},
$$

in which the strain rates, $(\partial u / \partial x),(\partial u / \partial y)$, etc., are defined in a Cartesian coordinate system with $x$ and $y$ axes in the horizontal plane, and $u$ and $v$ represent horizontal velocity in the $x$ and $y$ directions. The depth-average rate factor is computed:

$$
\bar{B}=\frac{1}{\left(z_{\mathrm{s}}-z_{\mathrm{b}}\right)} \int_{z_{\mathrm{b}}}^{z_{\mathrm{s}}}(E A)^{-\frac{1}{n}} \mathrm{~d} z
$$

using a temperature-dependent rate factor, $A$, and the flowlaw exponent $n$ (the usual value of 3 is used). The temperature dependence of the rate factor is expressed:

$$
A=a \exp \left(\frac{-Q}{R T^{*}}\right)
$$

in which the empirical constant, $a$, is equal to $3.61 \times 10^{-13} \mathrm{~Pa}^{-3}$ $\mathrm{s}^{-1}$ if $T<-10^{\circ} \mathrm{C}$ or $1.73 \times 10^{3} \mathrm{~Pa}^{-3} \mathrm{~s}^{-1}$ if $T \geq-10^{\circ} \mathrm{C}$, and the activation energy for ice creep, $Q$, is equal to $6.0 \times 10^{4} \mathrm{~J} \mathrm{~mol}^{-1}$ if $T<-10^{\circ} \mathrm{C}$, or $13.9 \times 10^{4} \mathrm{~J} \mathrm{~mol}^{-1}$ if $T \geq-10^{\circ} \mathrm{C}$. $R$ is the gas constant, $T$ is ice temperature and $T^{*}$ is the absolute temperature corrected for the pressure dependence of the melt temperature. It is common to multiply the rate factor, $A$, by an enhancement factor, $E$, in order to produce agreement between modeled and observed flow. The enhancement factor is meant to accommodate inaccuracy in the flow law or variations in ice structure or impurity content. The stress-balance portion of this model has been tested according to European Ice Sheet Modelling Initiative standards (MacAyeal and others, 1996).

Other formulations of the flow law are possible. It has been suggested that at the small stresses typically experienced by small ice shelves $(<10 \mathrm{kPa})$, it is more correct to treat separately dislocation creep $(n=3)$ and diffusion creep $(n=1)$ (Lliboutry and Duval, 1985), or that Glen's flow law should be used with an exponent $n=1$ (Hooke, 1981). Strain rates and stresses computed for the Larsen Ice Shelf (mean values are $\sim 2 \times 10^{-3} \mathrm{a}^{-1}$ and $\sim 22 \mathrm{kPa}$, respectively) are only slightly larger than the threshold values suggested by those authors. However, other factors, such as pervasive crevassing, may obscure the distinctions between flow laws (Paterson, 1985; MacAyeal and Holdsworth, 1986). For simplicity and ease of comparison with other Larsen studies, we use the flow-law formulation of Equations (1) and (2) with an exponent $n=3$.

Boundary conditions used to solve the stress-balance equations represent the dynamic influence of the ocean at the calving front, the kinematic influence of ice flowing into the shelf from outlet glaciers in Graham Land, and snow accumulation on the upper surface of the ice shelf. Ice flow into the model domain is specified for the Leppard, Crane, Evans and Hektoria, Drygalski and Dinsmoor/Bombardier outlets (0.27, 0.96, 0.55, 0.60 and $0.49 \mathrm{~m} \mathrm{~d}^{-1}$, respectively; Bindschadler and others, 1994; Doake and others, 1998). A no-slip condition is specified where there is no glacier inflow across the grounding line, at bay walls and around nunataks. Reduced ice strength at bay-wall margins (e.g. due to shear-strain heating or brine infiltration) is simulated by reducing the value of the flow-law rate factor in model mesh elements adjacent to the margins. The accumulation rate is $0.18 \mathrm{~m} \mathrm{a}^{-1}$ ice equivalent across the entire shelf (Rott and others, 1996). Basal melting is not included in the stress-balance calculations (although the thermal modelling implies a small, spatially uniform amount). Ice-shelf thickness (Fig. 6) is derived from observed surface elevation (Bamber and Bindschadler, 1997) and is similar to the thickness computed by Doake and others (1998).

A reasonable estimate of the flow-law rate factor, $A$, is fundamentally important to the stress-balance determination and depends greatly on the internal temperature of the shelf. A simple scheme to estimate the rate factor is to assume no knowledge of ice temperature and use trial and error to infer a spatially uniform value (which is really a mixture of $A$ and $E$ in Equation (2) that provides a good fit between modeled and observed ice flow (e.g. Hulbe and others, 1997; Doake and others, 1998)). Another simple approach is to assume that ice temperature is in equilibrium with the mean annual air temperature at the shelf surface and the melt temperature at the 
base of the shelf. A linear temperature profile between surface and base provides a rate factor according to Equation (3). A comparison between modeled and observed speed is used to determine the accompanying enhancement factor. A slightly more complicated scheme supposes that temperature in the ice shelf is influenced by inflow from mountain glaciers and is therefore unlikely to be in equilibrium with the surface and basal temperatures alone. The importance of grounded-ice discharge into the Larsen was noted by Rott and others (1996) on the basis of mass-balance arguments. The supply of relatively cold mountain-glacier ice implies that the interior shelf temperature is likely cooler than an equilibrium between local surface and basal temperatures. Other ice shelves in which grounded-ice influx contributes significantly to the mass of the shelf are observed to be relatively cold at mid-depth (e.g. Filchner Ice Shelf (Paterson, 1994, p. 236), George VI Ice Shelf (personal communication from D. E. Sugden, 1998)). Given the likely importance of the Graham Land glaciers to the mass balance of the ice shelf, we choose a heat-balance model to simulate their effect on the temperature of the ice shelf, and thus the rate factor used in stress-balance calculations.

Heat balance in the ice shelf is described by an advective/ diffusive equation:

$$
\frac{\partial T}{\partial t}+u \frac{\partial T}{\partial x}+v \frac{\partial T}{\partial y}+w \frac{\partial T}{\partial z}=\frac{1}{\rho c} \frac{\partial}{\partial z}\left(k \frac{\partial T}{\partial z}\right),
$$

where $T$ is temperature, $\rho$ is the density of ice, $c$ is heat capacity, $k$ is heat conductivity and $w$ is the vertical component of velocity. The thermal boundary conditions consider the effect of relatively cold ice flowing from the mountains into the ice shelf, mean annual surface air temperature and a basal temperature. The inflow temperature profile is computed using an analytic solution to the heat-flow equations (Paterson, 1994) with a surface temperature of $-15^{\circ} \mathrm{C}$ and accumulation rate of $0.44 \mathrm{~m} \mathrm{a}^{-1}$ (measured at Dyer Plateau; Thompson and others, 1994), and a geothermal heat flow of $0.0546 \mathrm{~W} \mathrm{~m}^{-2}$. Ice-shelf surface temperature is specified to be $-10^{\circ} \mathrm{C}$ (a pre-1981 mean annual value; Vaughan and Doake, 1996). We select a basal temperature of $-4^{\circ} \mathrm{C}$, a value which assumes some removal of warm basal ice by an active basal melting regime.

We estimate ice-shelf temperature by iterating the heatbalance portion of the model. The initial condition is isothermal at the coolest ice inflow temperature $\left(-15^{\circ} \mathrm{C}\right)$, with the other boundary conditions as described above. Periodically, the updated ice temperature is used to compute new flow-law rate factors, strain rates and velocities for comparison with measurements along a transect in the central region of Larsen B (from Rack and others, in press). For each new temperature field, the effects of various enhancement factors and boundary-layer softening are tested. When the modeled flow agrees with observed flow, the corresponding temperature field and rate factors are assumed to represent the present-day ice shelf.

Our preferred ice-shelf temperature distribution is on average about $7^{\circ} \mathrm{C}$ cooler than the surface temperature and about $4^{\circ} \mathrm{C}$ cooler than a temperature profile that varies linearly from surface to base (Fig. 7). This requires an enhancement factor of 8 to simulate strain rates along a profile measured on the surface of the shelf (Fig. 8; cf. fig. 4 of Rack and others, in press). An equivalent match to the flow field is achieved with a linear temperature profile between a surface temperature of $-10^{\circ} \mathrm{C}$ and a melting-point basal temperature,

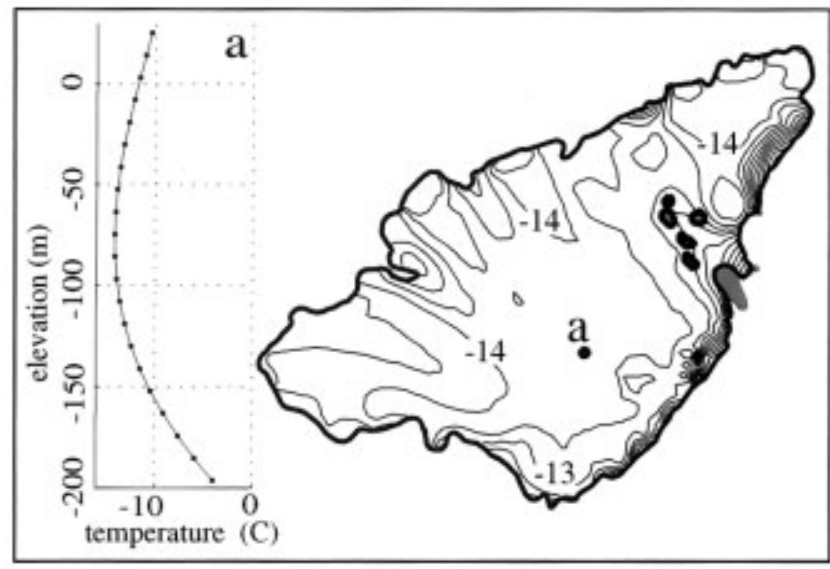

Fig. 7. Map of ice-shelf temperature at mid-depth (the tenth vertical node from the base of the ice shelf) and the depth profile of temperature at the mid-shelf location marked by a solid circle labelled " $a$ ". The contour interval is $0.5^{\circ} \mathrm{C}$. Points plotted on the vertical profile indicate vertical nodes in the numerical model domain.

given an enhancement factor of 3 . For both of these temperature patterns, the ice stiffness must be reduced by $85-90 \%$ along the shelf margins in order to reproduce the observed ice speed. This additional enhancement is likely due to the effects of shear, either through fracturing and brine infiltration or through shear heating of the margin (e.g. MacAyeal and Holdsworth, 1986; Jacobson and Raymond, 1998). While our preferred solution is not unique, it attempts to emulate the physical environment of the northern Larsen.
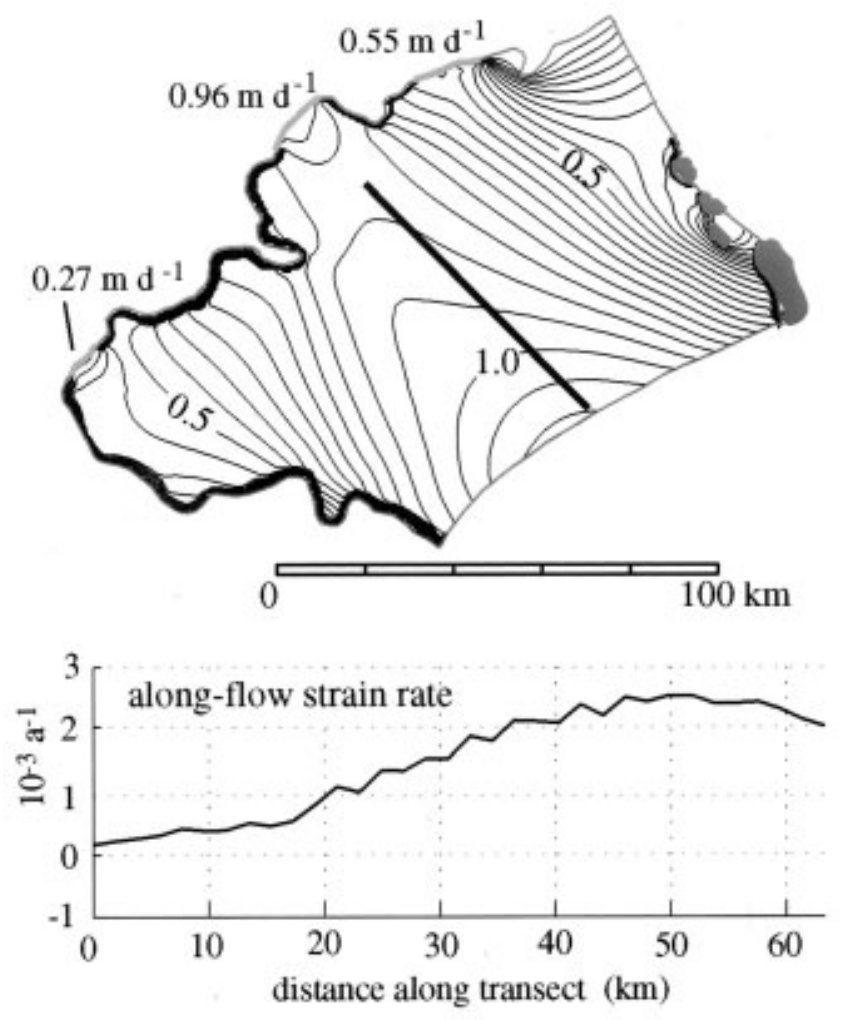

Fig. 8. Modeled ice flow for the post-calving, February 1995 Larsen B. The contour interval in the map of ice speed is $0.05 \mathrm{~m}^{-1}$. Isotachs deviate toward the southern part of the shelf because margin softening has a strong effect along the southern bay wall. Profiles of ice speed and the along-flow strain rate approximate the measured profile of Rack and others (2000). 


\section{Larsen B stress-balance results}

\section{Flow speed}

The numerical model is used to compute strain rates and stresses according to the boundary conditions and preferred ice temperature discussed above. We modify the finite-element mesh of Figure 6 to represent a sequence of geometries for the Larsen B after the large calving event in 1995. The mesh is refined to ensure adequate resolution around sharp features such as the jagged shelf front of November 1998. Not all experiments are shown here; instead we select those which provide the most insight into our proposed shelf-retreat mechanism. The temperature field computed for the pre1995 ice shelf is interpolated to each new model mesh and used to compute spatially variable flow-law rate factors, which in turn allow us to simulate ice flow. Figure 9 shows modeled ice speed along the Figure 8 profile for four different Larsen B geometries.

To match the field measurements, and the strain rates implied by interferometric analysis of the ice flow (Rott and others, 1998; Rack and others, in press), it was necessary to adjust the ice stiffness of the shear margins in the model between the pre-calving (pre-1995) state and subsequent iceshelf conditions. A stiffness decrease of $5 \%$ in the margins after the calving best reproduces all the data available. Alternatively, we might have adjusted the enhancement factor uniformly across the shelf to achieve the best velocity match; however, changing this parameter caused strain rates to differ significantly from the values inferred from the interferogram in Rack and others (1999).

For the post-calving velocity profiles (Fig. $9 b-d$ ), a steady velocity increase is observed as the front changes shape due to a series of break-up events. This is due to decreased compressive stresses in the northern two-thirds of the Larsen B after break-ups (Fig. 10).

\section{Tensile stresses}

The magnitudes of principal stresses for February 1995 and November 1998 Larsen B geometries are mapped in Figure 10. The stress patterns for intermediate ice-shelf geometries are similar. In general, a tensile stress of $30-80 \mathrm{kPa}$ is required for active single-crevasse formation (Fischer and others, 1995; Van der Veen, 1998). New-crevasse formation in heavily crevassed regions requires larger stresses. For all geometries, tensile stress is large where ice is shearing rapidly past bay-wall margins. Elsewhere, tensile stresses are small, $\sim 20 \mathrm{kPa}$, and pre-existing crevasses would tend to

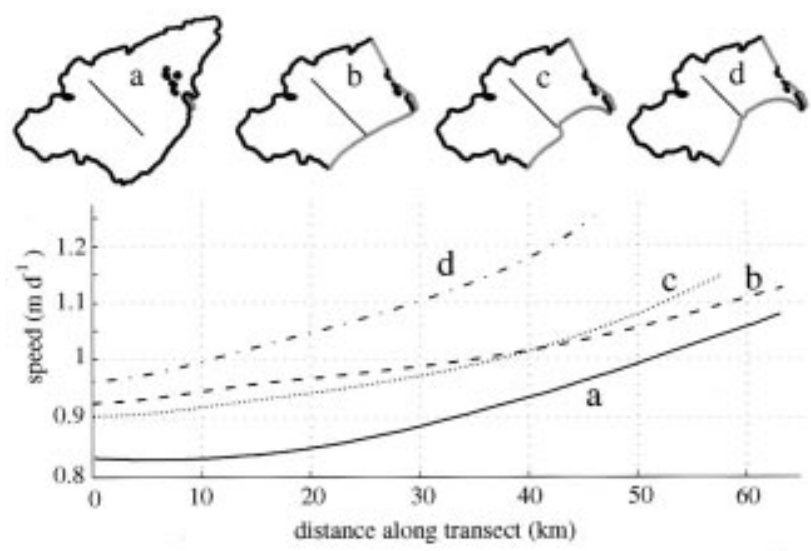

Fig. 9. Ice speed along the Figure 8 profile for four different ice-shelf geometries, as indicated by the labeled outlines. close. If crevasses formed at the corners of glacier inlets (Fig. 2) are to become the planes of weakness along which the ice shelf breaks apart, as we infer from the pattern of retreat observed along the northern half of the main Larsen B, some extra agent must keep the crevasses open as they advect toward the ice front.
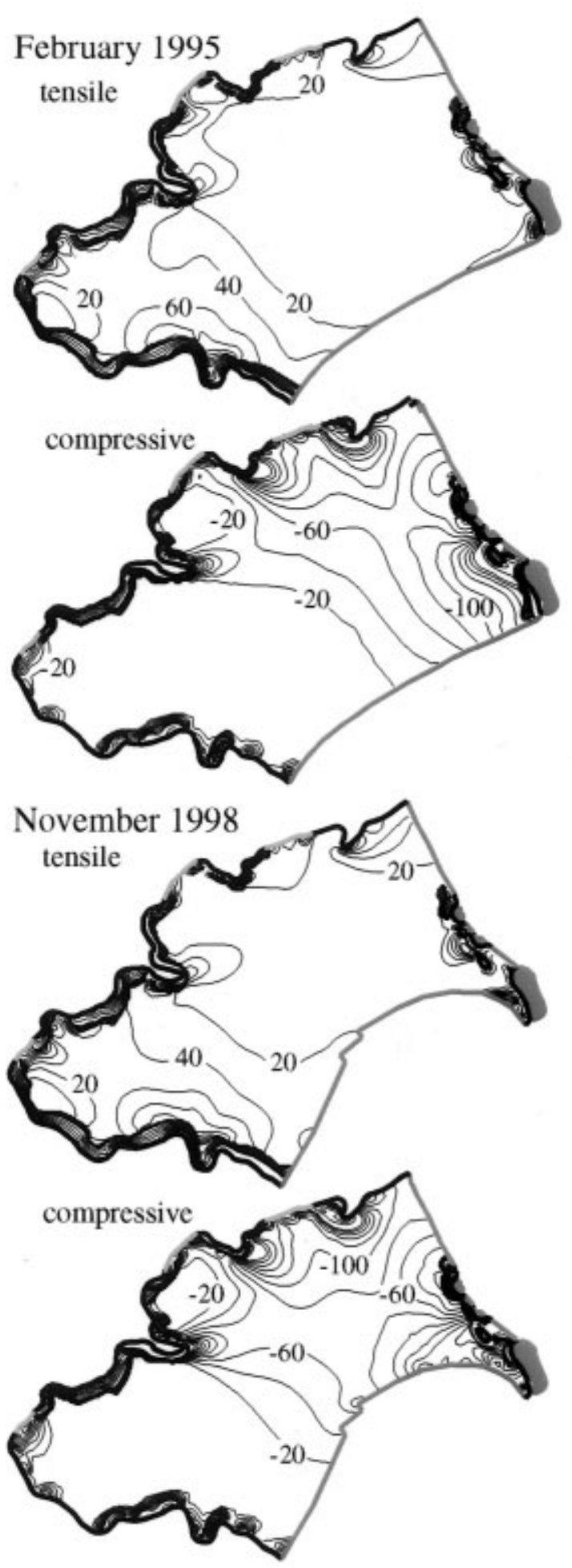

0

$100 \mathrm{~km}$

Fig. 10. Magnitude of the model-computed principal stresses for the March 1995 and November 1998 Larsen B geometries. The contour interval in all maps is $20 \mathrm{kPa}$. A tensile stress of at least 30-80 kPa is necessary for new single-crevasse initiation. Stresses are very large along bay walls, where substantial ice softening is specified. The least compressive principal stress is used to compute stress-intensity factors at crevasse tips. 


\section{Water-filled crevasses}

\section{Crevasses and the flow model}

Icebergs calve along fracture planes that either grow near the shelf front or have been advected toward the front from elsewhere. Large tensile stresses due to vertical stress gradients at the shelf front generate crevasses very close to the shelf front, within a distance of one ice thickness or so (Fastook and Schmidt, 1982). Other crevasses form at the corners of glacier outlets or along coastal shear margins. This older population of crevasses may be affected by many processes as they progress toward the shelf front, and probably play a role in the calving of large icebergs. A third possible source of crevasses, or special stresses that could modify existing crevasses, is the ocean upon which the ice shelf floats. Basal traction from subice currents, or flexure of the shelf by tides, storm surges or long-wavelength ocean swell is an ongoing process that could become more important in a weakened ice shelf.

The retreat pattern of the Peninsular shelves suggests some kind of enhancement of crevasses that originate far from the shelf front. Both the Wilkins and the Larsen A and $\mathrm{B}$ ice shelves show increased frequency of calving of elongate shards of ice 1-10 ice thicknesses in width along the shelf front, and, revealingly, this type of calving is associated with areas showing frequent melt-ponding as noted above.

The role of meltwater in ice-shelf break-up is most logically a result of its effect on crevasses. First, meltwater filling existing surface crevasses could allow them to remain open under conditions unfavorable for new crevasse formation. Second, meltwater filling allows crevasses to penetrate deeply within the shelf, perhaps through the full ice thickness. These ideas derive from the work of Weertman (1973) and Van der Veen (1998).

Water-filled crevasses penetrate more deeply than airfilled crevasses because the water pressure opposes the ice overburden pressure, or lithostatic stress. The competing effects may be quantified for an individual crevasse as a "stress-intensity factor", $K_{i}$, which embodies the effects of tensile stress on crevasse walls, lithostatic stress and water pressure (Van der Veen, 1998). Following Van der Veen (1998), the effect of tensile stress is expressed:

$$
K_{i}^{1}=F(\lambda) R_{x x} \sqrt{\pi d},
$$

where $F(\lambda)$ is an empirically derived function of the ratio of crevasse depth, $b$, to ice thickness. The resistive stress $R_{x x}$ is defined as the full stress minus the lithostatic stress (e.g. Van der Veen and Whillans, 1989). Consistent with the governing equations of the stress-balance model, $R_{x x}$ is constant with depth. The lithostatic stress, which tends to close crevasses, varies with depth and with ice density (which is also a function of depth), so its contribution to the stress-intensity factor must be integrated over the depth of the crevasse:

$$
K_{i}^{2}=\frac{2 \rho_{\mathrm{i}} g}{\sqrt{\pi d}} \int_{0}^{d}\left[-b+\frac{\rho_{\mathrm{i}}-\rho_{\mathrm{s}}}{\rho_{\mathrm{i}} C}\left(1-\mathrm{e}^{-C b}\right)\right] G(\gamma, \lambda) \mathrm{d} b .
$$

Ice density varies from a surface snow value, $\rho_{\mathrm{s}}$, to that of solid ice, $\rho_{\mathrm{i}}$, according to the empirical relation $\rho(b)=$ $\rho_{\mathrm{i}}-\left(\rho_{\mathrm{i}}-\rho_{\mathrm{s}}\right) \mathrm{e}^{-C b}$ (Paterson, 1994, p. 16), in which $C$ is a constant, taken here to be $0.02 \mathrm{~m}^{-1}$. $G$ is a numerically derived function of the ratios $\gamma=b / d$, and $\lambda$. Lastly, the contribution of water pressure to stress intensity is expressed:

$$
K_{i}^{3}=\frac{2 \rho_{\mathrm{w}} g}{\sqrt{\pi d}} \int_{a}^{d}(b-a) G(\gamma, \lambda) \mathrm{d} b
$$

where $\rho_{\mathrm{w}}$ is the density of water and $a$ is the depth below the ice surface of the water level in the crevasse. The stress-intensity factor acting at the tip of a single crevasse is the sum of the solutions to Equations (5-7), given some assumed values for surface snow density, ice density and water level.

Several assumptions must be made in order to employ the crevasse-tip stress-intensity equations. First, we must select appropriate firn and ice densities. Both ablation and percolation of surface meltwater through the firn will densify the upper part of the ice shelf, so we select a relatively large value, $850 \mathrm{~kg} \mathrm{~m}^{-2}$. A smaller surface density would yield a smaller overburden pressure at any given depth. The ice density is assumed to be $917 \mathrm{~kg} \mathrm{~m}^{-1}$. Second, we must select a water-filling depth, $a$. The water is most effective when crevasses are brim-full, but subsurface water levels are probably more typical. Water levels of 0.1 and $2 \mathrm{~m}$ below the surface, respectively, represent those two conditions in the calculations here. The stress-intensity factor calculations are idealized and neglect the intensity-reducing effects of multiple crevasses (Van der Veen, 1998) and so cannot be used to predict exactly where crevasse tips will crack downward through the full shelf thickness. However, they can be used to evaluate the viability of meltwater as a mechanism to enhance crevasse penetration in the Larsen Ice Shelf.

In the process of testing the crevasse stress-intensity model, we conducted a series of forward calculations, in which combined stress-intensity factors are calculated for various levels of water-filling in crevasses of many depths and orientations. In all our experiments, crevasses more than $90 \%$ filled tend to open, while those with lower water levels tend to close, as shown for the general case by Van der Veen (1998).

\section{Crevasse-opening depth}

The stress-intensity equations may be inverted to estimate crevasse penetration, given an assumption about the fracture toughness of the ice. The fracture toughness of glacier ice is not well known, but a reasonable estimate is that it lies within the range $100-400 \mathrm{kPa} \mathrm{m}^{-2}$ (Van der Veen, 1998). Stress intensity must meet or exceed that range before a crevasse tip, either water- or air-filled, can crack downward into the ice shelf. While it is generally the case that a waterfilled crevasse in glacier ice will penetrate the full ice thickness (Van der Veen, 1998), several features of the Larsen B conspire against crevasse opening. First, tensile stresses in the main body of the shelf are small (see Fig. 10). Second, because the surface density is likely to be near the density of glacier ice (instead of firn), near-surface lithostatic pressure will be relatively large. The result is that near-surface stress-intensity factors are negative, or so small that the outward pressure of meltwater filling a crevasse is insufficient to counteract the tendency for the crevasse to close. With increasing crevasse depth, and thus increasing water depth, the net stress intensity at the crack tip grows more positive. Below some critical depth, the net stress intensity exceeds the fracture toughness of the ice, and the crevasse tip will crack downward, and continue cracking unless the ambient stress field or degree of water-filling changes. 
Modeled stresses allow us to invert the stress-intensity equations and estimate the depth at which the net stress intensity at a crevasse tip will exceed the fracture toughness of the ice. If a pre-existing crevasse (presumably advected from the grounding line into the main body of the shelf or formed in a bay-wall shear margin) is deeper than modelderived critical depth range, water-filling would likely cause the crevasse to crack downward through the full ice thickness. If we can reasonably expect pre-existing crevasses to be within or deeper than the critical depth range, we may predict that abundant surface melting will lead to pervasive rifting, and eventual mechanical failure, of the ice shelf. We repeat the inversion for many ice-shelf geometries, using the most positive principal tensile stress for $R_{x x}$ in Equation (5). Thus, we produce a "best-case" critical depth; greater depths would be required for crevasses not oriented according to the principal stresses.

Maps of critical crevasse depth for the February 1995 and November 1998 Larsen B geometries, and several water-filling and surface density scenarios are shown in Figure 11. With a large surface density, $850 \mathrm{~kg} \mathrm{~m}^{-3}$, and a water level $2 \mathrm{~m}$ below the shelf surface, pre-existing crevasses in much of the shelf must be at least 16-22 m deep if water-filling is to cause them to crack downward through the full ice thickness and if the fracture toughness of the ice is $100 \mathrm{kPa} \mathrm{m}^{1 / 2}$ (Fig. 1la). With all other variables as in the first experiment, brim-full crevasses need only have initial depths of 4-6 m
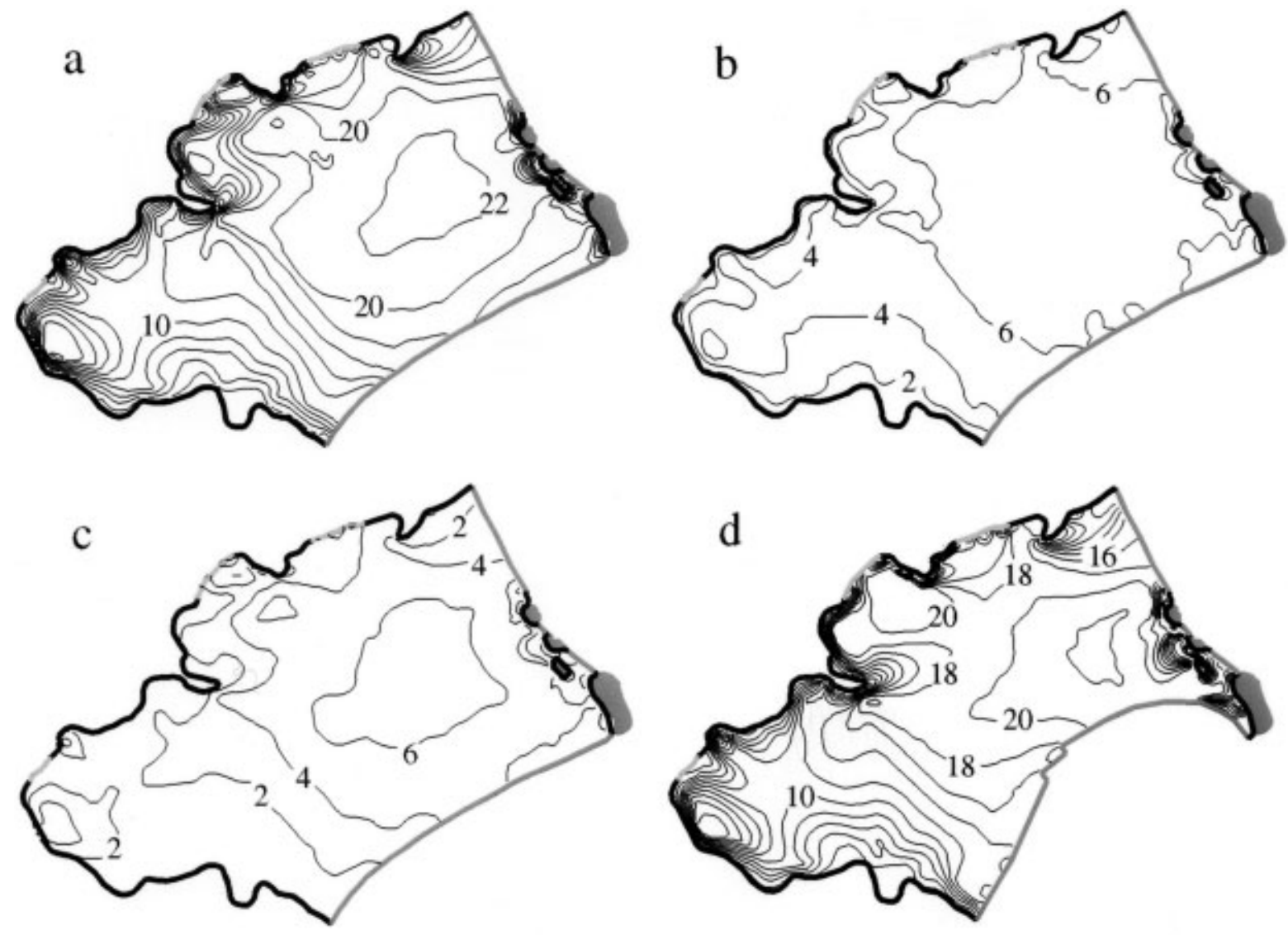

(Fig. 1lb). If the fracture toughness is closer to the upper limit of its estimated range, $400 \mathrm{kPam}^{1 / 2}$, pre-existing crevasses must be 24-30 m deep before water-filling becomes important (10-14 $\mathrm{m}$ for brim-full crevasses). Lower surface densities promote larger stress intensities at shallower depths. With a surface density of $750 \mathrm{~kg} \mathrm{~m}^{-3}$ and a water level of $2 \mathrm{~m}$, crevasses must be 10-14 $\mathrm{m}$ deep for weaker ice or 16-18 $\mathrm{m}$ deep for stronger ice. For a more firn-like surface density of $450 \mathrm{~kg} \mathrm{~m}^{-3}$, initial crevasse depths of $6-10 \mathrm{~m}$ are sufficient for water-filling to induce deep cracking (Fig. 11c). Changing calving-front geometry has little effect on critical crevasse depth (Fig. 1ld). It is interesting to note that the generally larger tensile stresses in the southernmost part of Larsen B result in shallower critical crevasse depths, yet the southern front of the shelf was slower to retreat than its northern counterpart. The incongruity may be explained by the absence of surface melt-ponding in the southern region of Larsen B.

The modeled critical crevasse depths seem reasonable and we conclude that our hypothesized mechanism for iceshelf disintegration by meltwater ponding and consequent deep fracturing of the ice is valid. Indeed, for brim-full crevasses, even very shallow initial crevasses can be induced to crack through the whole ice-shelf thickness. We cannot predict the rate of downward crevasse-tip propagation, but observation suggests that it must occur within one melt season, because cold winter temperatures and cold interior ice would refreeze a past summer's meltwater.

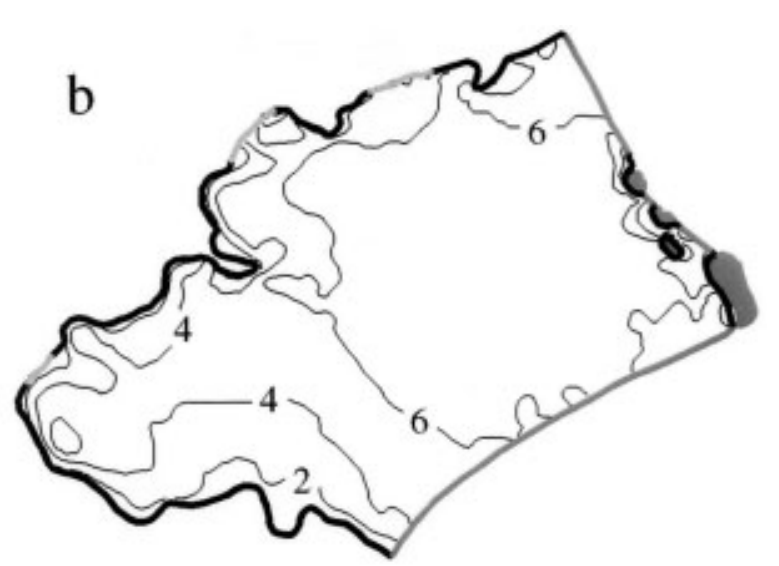

0 $100 \mathrm{~km}$

Fig. 11. "Critical depth"for pre-existing crevasses computed by inversion of the single-crevasse stress-intensity equations. Pre-existing crevasses deeper than the critical depth, when filled to the specified water level, would crack downward through the full ice thickness. Critical depth for three combinations of assumed surface density and water depth in the February 1995 Larsen B are shown, along with one example using the November 1998 geometry. The contour interval is $2 \mathrm{~m}$. (a) Surface density, $\rho$, is assumed to be $850 \mathrm{~kg} \mathrm{~m}^{-3}$, and the water depth, $a$, is $2 \mathrm{~m}$ below the ice surface; (b) $\rho=850 \mathrm{~kg} \mathrm{~m}^{-3}$ and $a=0.1 \mathrm{~m}$; (c) $\rho=450 \mathrm{~kg} \mathrm{~m}^{-3}$ and $a=2 \mathrm{~m} ;(d) \rho=850 \mathrm{~kg} \mathrm{~m}^{-3}$ and $a=2 \mathrm{~m}$. The fracture toughness of ice is assumed to be $100 \mathrm{kPa} \mathrm{m}$. 


\section{DISCUSSION}

The numerical experiments allow us to draw conclusions about many of the satellite-based observations of ongoing changes in ice shelves around the Antarctic Peninsula. For the example studied in most detail here, the Larsen B Ice Shelf, crevasse deepening by meltwater filling is a viable explanation for the rapid, ongoing retreat of the shelf front. Meltwater ponding does not initiate new crevassing. Rather, meltwater filling existing crevasses can allow the crevasses to penetrate more deeply than air-filled crevasses. The inverse calculations for Larsen B show that only modest pre-existing crevasse depths (a few tens of meters or less) are needed for water-filling to induce crevasse deepening. Crevasses formed at the corners of glacier outlets and advected into the body of the ice shelf are likely to meet that requirement, as are small flexure- or basal-drag-generated crevasses formed by interaction with the ocean. Thus, our observation-based hypothesis that pervasive surface melting is linked closely to rapid ice-shelf disintegration is supported.

Although the correlation between melt-ponding and break-up is very clear for the studied shelves, there are other shelves which show melt ponds but do not appear to be in rapid retreat, such as the George VI Ice Shelf (as noted above) and the Amery Ice Shelf. That may be due to overall smaller or negative normal stresses in those ice shelves or to differences in shelf-ocean interaction. Both shelves are relatively well protected, long and narrow. In the case of the Amery, it is likely that the stress regime is compressive within the region of frequent annual melting, which is well away from the ice front (Swithinbank, 1988; Phillips, 1998).

We suggest that most ice shelves that begin to show frequent melt-ponding near the shelf front will retreat via the mechanisms discussed above. The most susceptible ice shelves, based on current seasonal melt activity (Zwally and Fiegles, 1994), are the Larsen C and the shelves fringing the East Antarctic north coast (Riiser-Larsen, Fimbul, West and Shackleton shelves). Currently the Ross Ice Shelf shows frequent surface melting during warmer summers, but never meltponding. The Filchner-Ronne Ice Shelf is colder and has little seasonal melting.

\section{ACKNOWLEDGEMENTS}

This study was supported by NASA grant NAG5-4179 and by a NASA Graduate Student Fellowship in Global Change Research and subsequent U.S. National Research Council Research Associateship to C. L. Hulbe. C. Rosanova provided a portion of a mosaic of ERS-1 SAR data of the peninsula for Figure 2. R. Bauer provided assistance with DISP images and historical maps of the ice shelves.

\section{REFERENGES}

Abdalati, W. and K. Steffen. 1997. Snowmelt on the Greenland ice sheet as derived from passive microwave satellite data. f. Climate, 10(2), 165-175.

American Geographical Society (AGS). 1962. Antarctica. (Scale 1:3,000,000.) Washington, DC, American Geographical Society; U.S. National Science Foundation Antarctic Research Programme. (map.)

American Geographical Society (AGS). 1971. Antartica. (Scale 1:5,000,000.) Washington, DC, American Geographical Society; U.S. National Science Foundation Antarctic Research Programme. (map.)

Bamber, J. L. and R. A. Bindschadler. 1997. An improved elevation dataset for climate and ice-sheet modelling: validation with satellite imagery. Ann. Glaciol., 25, 439-444.

Bertrand, K. J. 1971. Americans in Antarctica 1775-1948. New York, American
Geographical Society. (Special Publication 39.)

Bindschadler, R. A., M. A. Fahnestock, P. Skvarca and T. A. Scambos. 1994. Surface-velocity field of the northern Larsen Ice Shelf, Antarctica. Ann. Glaciol., 20, 319-326.

Comiso, J. C. 2000. Variability and trends in Antarctic surface temperatures from in situ and satellite infrared measurements. f. Climate, 13(10), 1674-1696.

Cooper, A. P. R. 1997. Historical observations of Prince Gustav Ice Shelf. Polar Rec., 33(187), 285-294.

Doake, C. S. M. 1982. State of balance of the ice sheet in the Antarctic Peninsula. Ann. Glaciol., 3, 77-82.

Doake, C. S. M. and D. G. Vaughan. 1991. Rapid disintegration of the Wordie Ice Shelf in response to atmospheric warming. Nature, 350 (6316), 328-330.

Doake, C. S. M., H. F. J. Corr, H. Rott, P. Skvarca and N. W. Young. 1998. Break-up and conditions for stability of the northern Larsen Ice Shelf, Antarctica. Nature, 391(6669), 778-780.

Fahnestock, M. A., T. A. Scambos and W. Payne. 1998. Summer snow melt patterns and the disintegration of ice shelves on the Antarctic Peninsula. [Abstract.] EOS, 79(45), Fall Meeting Supplement, F327.

Fahnestock, M. A., T. A. Scambos, R. A. Bindschadler and G. Kvaran. In press. A millennium of variable ice flow recorded by the Ross Ice Shelf, Antarctica. 7. Glaciol.

Fastook, J. L. and W. F. Schmidt. 1982. Finite element analysis of calving from ice fronts. Ann. Glaciol., 3, 103-106.

Ferrigno, J. G. and 7 others. 1996. Antarctica. (Scale 1:5,000,000.) U.S. Geol. Surv. Misc. Field Invest. Map I-2560.

Fischer, M. P., R. B. Alley and T. Engelder. 1995. Fracture toughness of ice and firn determined from the modified ring test. f. Glaciol., 41 (138), 383-394.

Hooke, R. LeB. 1981. Flow law for polycrystalline ice in glaciers: comparison of theoretical predictions, laboratory data, and field measurements. Rev. Geophys. Space Phys., 19(4), 664-672.

Hughes, T. 1983. On the disintegration of ice shelves: the role of fracture. $\mathcal{F}$. Glaciol., 29(101), 98-117.

Hulbe, C. L., T. Scambos and J. A. Bohlander. 1997. Ice shelf break-up and retreat in the Antarctic Peninsula and factors affecting ice shelf stability. [Abstract.] EOS, 78(46), Fall Meeting Supplement, F249.

Jacobs, S. S. and J. C. Comiso. 1997. Climate variability in the Amundsen and Bellingshausen Seas. 7. Climate, 10(4), 697-709.

Jacobson, H. P. and C. F. Raymond. 1998. Thermal effects on the location of ice stream margins. F. Geophys. Res., 103(B6), 12,111-12,122.

King, J. C. 1994. Recent climate variability in the vicinity of the Antarctic Peninsula. Int. 7. Climatol., 14(4), 357-369.

Koerner, R. M. 1961. Glaciological observations in Trinity Peninsula, Graham Land, Antarctica. F. Glaciol., 3(30), 1063-1074.

Lliboutry, L. and P. Duval. 1985. Various isotropic and anisotropic ices found in glaciers and polar ice caps and their corresponding rheologies. Annales Geophysicae, 3(2), 207-224.

Lucchitta, B. K. and C.E. Rosanova. 1998. Retreat of northern margins of George VI and Wilkins Ice Shelves, Antarctic Peninsula. Ann. Glaciol., 27, $41-46$.

MacAyeal, D. R. and G. Holdsworth. 1986. An investigation of low-stress ice rheology on the Ward Hunt Ice Shelf. 7. Geophys. Res., 91(B6), 6347-6358.

MacAyeal, D. R. and R. H. Thomas. 1982. Numerical modeling of ice-shelf motion. Ann. Glaciol., 3, 189-194.

MacAyeal, D. R., V. Rommelaere, P. Huybrechts, C. L. Hulbe, J. Determann and C. Ritz. 1996. An ice-shelf model test based on the Ross Ice Shelf, Antarctica. Ann. Glaciol., 23, 46-51.

Mercer, J. H. 1978. West Antarctic ice sheet and $\mathrm{CO}_{2}$ greenhouse effect: a threat of disaster. Nature, 271 (5643), 321-325.

Morland, L. W. 1987. Unconfined ice-shelf flow. In Van der Veen, C. J. and J. Oerlemans, eds. Dynamics of the West Antarctic ice sheet. Dordrecht, etc., D. Reidel Publishing Co., 99-116.

Nordenskiöld, O. 1905. Antarctica. London, Hurst \& Blackett, Ltd.

Paterson, W. S. B. 1985. Flow law for ice in polar ice sheets. Nature, 318(6041), 82-83.

Paterson, W. S. B. 1994. The physics of glaciers. Third edition. Oxford, etc., Elsevier.

Phillips, H. A. 1998. Surface meltstreams on the Amery Ice Shelf, East Antarctica. Ann. Glaciol., 27, 177-181.

Rack, W., H. Rott, A. Siegel and P. Skvarca. 1999. The motion field of northern Larsen Ice Shelf, Antarctic Peninsula, derived from satellite imagery. Ann. Glaciol., 29, 261-266.

Rack, W., C. S. M. Doake, H. Rott, A. Siegel and P. Skvarca. In press. Interferometric analysis of the deformation pattern of the northern Larsen Ice Shelf, Antarctic Peninsula, compared to field measurements and numerical modelling. Ann. Glaciol., 31.

Reynolds, J. M. 1981. Lakes on George VI Ice Shelf, Antarctica. Polar Rec., 20 (128), 425-432.

Ridley, J. 1993. Surface melting on Antarctic Peninsula ice shelves detected by passive microwave sensors. Geophys. Res. Lett., 20(23), 2639-2642.

Rommelaere, V. and C. Ritz. 1996. A thermomechanical model of ice-shelf 
flow. Ann. Glaciol., 23, 13-20.

Rott, H., P. Skvarca and T. Nagler. 1996. Rapid collapse of northern Larsen Ice Shelf, Antarctica. Science, 271(5250), 788-792.

Rott, H., W. Rack, T. Nagler and P. Skvarca. 1998. Climatically induced retreat and collapse of northern Larsen Ice Shelf, Antarctic Peninsula. Ann. Glaciol., 27, 86-92.

Skvarca, P. 1993. Fast recession of the northern Larsen Ice Shelf monitored by space images. Ann. Glaciol., 17, 317-321.

Skvarca, P. 1994. Changes and surface features of the Larsen Ice Shelf, Antarctica, derived from Landsat and Kosmos mosaics. Ann. Glaciol., 20, 6-12.

Skvarca, P., W. Rack and H. Rott. 1999. 34 year satellite time series to monitor characteristics, extent and dynamics of Larsen B Ice Shelf, Antarctic Peninsula. Ann. Glaciol., 29, 255-260.

Swithinbank, C. 1988. Antarctica. U.S. Geol. Surv. Prof. Pap. 1386-B, B1-B138.

Thompson, L. G. and 7 others. 1994. Climate since AD 1510 on Dyer Plateau, Antarctic Peninsula: evidence for recent climate change. Ann. Glaciol., 20, 420-426

Turner, J., S. Leonard, T. Lachlan-Cope and G. J. Marshall. 1998. Understanding Antarctic Peninsula precipitation distribution and variability using a numerical weather prediction model. Ann. Glaciol., 27, 591-596.
Van der Veen, C. J. 1998. Fracture mechanics approach to investigating conditions leading to ice-shelf break-up. In Chapman Conference on the West Antarctic Ice Sheet, 13-18 September 1998, Orono, Maine. Abstracts. Washington, DC, American Geophysical Union.

Van der Veen, C. J. and I. M. Whillans. 1989. Force budget: I. Theory and numerical methods. F. Glaciol., 35(119), 53-60.

Vaughan, D. G. and C. S. M. Doake. 1996. Recent atmospheric warming and retreat of ice shelves on the Antarctic Peninsula. Nature, 379(6563), 328-331.

Vaughan, D. G., D. R. Mantripp, J. Sievers and C. S. M. Doake. 1993. A synthesis of remote sensing data on Wilkins Ice Shelf, Antarctica. Ann. Glaciol., 17, 211-218.

Wager, A. C. 1972. Flooding of the ice shelf in George VI Sound. Br. Antarct. Surv. Bull. 28, 71-74.

Weertman, J. 1973. Can a water-filled crevasse reach the bottom surface of a glacier? International Association of Scientific Hydrology Publication 95 (Symposium at Cambridge 1969 - Hydrology of Glaciers), 139-145.

Zwally, H. J. and S. Fiegles. 1994. Extent and duration of Antarctic surface melt. F. Glaciol., 40(136), 463-476.

MS received 28 September 1999 and accepted in revised form 23 June 2000 